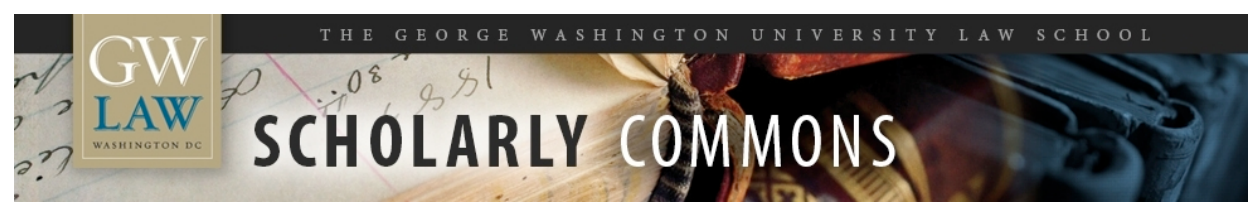

\title{
How Should We Respond to the Growing Risks of Financial Conglomerates?
}

Arthur E. Wilmarth Jr.

George Washington University Law School, awilmarth@law.gwu.edu

Follow this and additional works at: https://scholarship.law.gwu.edu/faculty_publications

Part of the Law Commons

\section{Recommended Citation}

Arthur E. Wilmarth Jr., How Should We Respond to the Growing Risks of Financial Conglomerates? in FINANCIAL MODERNIZATION AFTER GRAMM-LEACH-BLILEY (Patricia C. McCoy, Ed., Lexis Publishing Co., 2002).

This Book Part is brought to you for free and open access by the Faculty Scholarship at Scholarly Commons. It has been accepted for inclusion in GW Law Faculty Publications \& Other Works by an authorized administrator of Scholarly Commons. For more information, please contact spagel@law.gwu.edu. 


\title{
HOW SHOULD WE RESPOND TO THE GROWING RISKS OF FINANCIAL CONGLOMERATES?
}

\author{
Arthur E. Wilmarth, Jr. ${ }^{1}$
}

\section{Introduction}

Passage of the Gramm-Leach-Bliley Act $^{2}$ in November 1999 marked the beginning of a new regime for regulating financial services in the United States. The GLB Act swept away the prior legal constraints on affiliations among banks, securities firms and insurance companies. ${ }^{3}$ As a result, all three types of financial institutions may now combine to form financial conglomerates

1 Professor of Law, George Washington University Law School. B.A., Yale University; J.D., Harvard University. I gratefully acknowledge comments by participants in the conference on "Financial Modernization After Gramm-Leach-Bliley," held at Cleveland-Marshall College of Law on May 18, 2001, where I presented a preliminary version of this article. Special thanks go to Patricia McCoy, who organized the conference and provided very helpful suggestions. I am, of course, solely responsible for all remaining errors. Unless otherwise indicated, this article includes developments through October 20, 2001.

2 Act of Nov. 12, 1999, Pub. L. No. 106-102, 113 Stat. 1338 [hereinafter called the "GLB Act"]. For general discussions of the GLB Act, see Michael P. Malloy, Banking in the Twenty-First Century, 26 J. Corp. L. 787, 793-819 (2000); Michael K. O’Neal, Summary and Analys is of the Gramm-Leach-Bliley Act, 28 Sec. Reg. L. J. 95 (2000).

3 The GLB Act authorized full-scale affiliations between banks and securities firms by repealing Sections 20 and 32 of the Banking Act of 1933, popularly known as the "Glass-Steagall Act." See Act of Nov. 12, 1999, supra note 2, $\S 101,113$ Stat. 1341. The GLB Act did not repeal two other provisions of the Glass-Steagall Act - (i) Section 16, 12 U.S.C. § 24(S eventh), which prohibits banks from underwriting or dea ling in most types of securities, and (ii) Section 21, 12 U.S.C. $\S 378$, which bars securities underw riters and dea lers from engaging in the busines s of accepting deposits. Thus, the GLB Act removed the Glass-Steagall Act's restrictions on affiliations between banks and securities firms, but banks and securities firms each continue to be prohibited from engaging directly in the other industry's core activities. See Patric ia A. McCoy, Banking Law Manual $\S \S 7.01,7.02[1], 7.03[1], 7.03[3]$ \& 7.04 (2000); O’Neal, supra note 2, at 99-100.

For discussion of the GLB Act's removal of legal restrictions on affiliations between banks and insur ance companies, see Lissa L. Broome \& Jerry W. Markham, Banking and Insurance: Before and After the Gramm-Leach-Bliley Act, 26 J. Corp. L. 723, 748-61 (2000). 
under the umbrella structure of a "financial holding company."4

Even before the GLB Act was passed, the legal barriers to financial consolidation were "all but render[ed] . . . moot" by the FRB's approval of a merger between Citicorp and Travelers. ${ }^{5}$ This merger created a huge diversified financial holding company called "Citigroup," which currently ranks as the world's largest financial services organization. ${ }^{6}$ Proponents of financial modernization hailed Citigro up as the first modern American "universal bank," because it was the first U.S. banking organization since 1933 that could offer comprehensive banking, securities, and

${ }^{4}$ The GLB Act permits bank holding companies (viz., companies that control one or more banks) to become financial holding companies by registering with the Federal Reserve Board ("FRB"). The FRB has general super visory responsibility as the "umbrella regulat or" of financial holding companies. See O'Neal, supra note 2, at 104-06. Nonbank subsidiaries of financial holding companies may engage in activities that are designated as "financial in nature" in the GLB Act or in rulings made by the FRB after consultation with the Treasury Department. See Act of Nov. 12, 1999, supra note 2, § 103(a), 113 Stat. 1342-50 (codified at 12 U. S.C. $\S \S 1843(\mathrm{k})$ - (o)). The GLB Act expressly states that "financial in nature" activities include (i) insurance underwriting, sales, broker age and port folio inves tments, (ii) securities underwriting, dealing, market making and brokerage, and (iii) merchant banking. See 12 U.S.C. $\S \S$ 1843(k)(4)(B), (E) \& (F); McCoy, supra note 3, § 4.03.

The GLB Act also allows national banks and state banks insured by the Federal Deposit Insurance Corporation ("FDIC") to establish direct subsidiaries (known as "financial subsidiaries") that conduct most of the activities permitted to financial holding companies. However, financial subsidiaries of banks may not engage in insurance underwriting, ins ura nce company portfolio investments or merchant banking. See

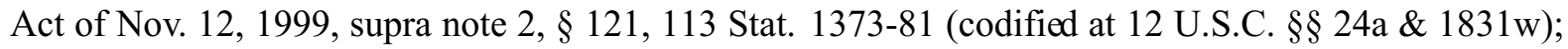
McCoy, supra note 3, $\S 4.06[1][\mathrm{a}]$; O’Neal, supra note 2, at 108-12.

${ }^{5}$ O’Neal, supra note 2, at 96.

${ }^{6}$ R. Christian Bruce, Fed Approves Citicorp-Tra velers Merger Creating World's Largest Bank Company, 71 BNA's Banking Rep. 449 (1998) [hereinafter cited as Bruce, Citicorp-Travelers Merger] (reporting that Citigroup would initially have assets of $\$ 750$ billion). By the second quarter of 2001, Citigroup had grown in size to $\$ 940$ billion and ranked first in the world in terms of both assets and market capitalization. See Niamh Ring, Citi Surpasses Deutsche As No. 1 in Asset Size, Am. Banker, July 6, 2001, at 2; The Business Week Global 1000, Bus. Week, July 9, 2001, at 75 (tbl.) (showing that Citigroup had a market capitalization of \$261 billion as of May 31, 2001, compared to \$116 billion for HSBC Holdings, the second most highly-valued global bank). 
insurance services to its custo mers. ${ }^{7}$

The FRB approved the Citicorp-Travelers merger in September 1998, even though the proposal "challenge[d] both the statutory letter and regulatory spirit" of existing law and Congress had not yet acted on pending financial modernization bills. ${ }^{8}$ Based on an exemption in the federal Bank Holding Company Act ("BHC Act"), the FRB's order allowed Citigroup to offer securities and insurance services beyond the scope of the BHC Act for up to five years after Citicorp merged with Travelers. ${ }^{9}$ In practical effect, the FRB gave Citigroup a five-year charter to o perate as a universal bank and did not require Citigro up to divest any of its nonconforming

7 See, e.g., Yvette D. Kantrow \& Liz Moyer, Citi, Travelers: A Global Leader Takes Shape, Am. Banker, April 7, 1998, at 1; Michael Siconolfi, Big Umbrella: Travelers and Citicorp Agree to Join Forces In $\$ 83$ Billion Merger, Wall St. J., April 7, 1998, at A1. As used herein, the term "universal banking" refers to a regime under which a single orga nization can engage (either directly or indirectly through affiliates) in all aspects of the banking, securities and life insurance businesses. See ANThONy SAUnders \& Ingo Walter, Universal Banking in the United States: What Could We Gain? What Could WE LosE? 84-86, 128-29 (1994) (adopting the same definition of "universal banking”).

${ }^{8}$ Edward J. Kane, Implications of superhero metaphors for the issue of banking powers, $23 \mathrm{~J}$. Banking \& Fin. 663 (1999) [hereinafter cited as Kane, Banking Powers], at 666 (quote), 669.

9 Under Section 4(a)(2) of the BHC Act, 12 U.S.C. $\S 1843(\mathrm{a})(2)$, a nonbanking company is exempt from the activity restrictions contained in Section 4 of the BHC Act for up to two years after it acquires a bank. In addition, Section 4(a)(2) authorizes the FRB to grant up to three one-year extensions of this exemption period. See Travelers Group, Inc., 84 Fed. Res. Bull. 985, 985-88 (1998) (relying on exemption provided in Section 4(a)(2)). In approving the Citicorp-Travelers merger, the FRB determined that about $25 \%$ of Tra velers' ass ets and $40 \%$ of Tra velers' revenues were related to opera tions that did not conform to the activity restrictions contained in Section 4 (in its pre-GLB Act version). Those nonconforming activities included, inter alia, underwriting life insurance and property and casualty insurance, investing in more than $5 \%$ of the voting shares of commercial companies, and controlling and distributing shares of mutual funds. See id. at 985, 988.

A federal appeals court subsequently upheld the FRB's order. The court concluded that the FRB's "literal compliance" with the exemption contained in Section 4(a)(2) rebutted any argument that the FRB had violated the "purposes" of the BHC Act. Independent Community Bankers of America v. Bd. of Governors, 195 F.3d 28, 31-32 (D.C. Cir. 1999). 
securities or insurance activities. ${ }^{10}$

From a political perspective, Citigroup's leaders "boldly gambled that they [could] dragoon Congress . . . into legalizing their transformation" before the exemption period expired. ${ }^{11}$ Citigroup's gamble proved to be well founded when Congress passed the GLB Act less than fourt een months after the FRB approved the Citicorp-Travelers merger. The regulatory and legislative responses to the merger raise troubling questions about (i) the degree of political influence enjoyed by Citigroup and other major financial institutions, ${ }^{12}$ and (ii) the FRB's willingness to pressure Congress by confronting it with the choice of either approving legislation

${ }^{10}$ See, e.g., Bruce, Citicorp-Travelers Merger, supra note 6.

${ }_{11}$ Kane, Banking Powers, supra note 9, at 666. See also Dean Anason, Advocates, Skeptics Face Off on Megadeals, Am. Banker, April 30, 1998, at 1 [hereinafter cited as Anason, Megadeals], at 2 (reporting that Citigroup's formation "was widely seen as a bid to push lawmakers to enact a sweeping overhaul of financial laws," and quoting Rep. Maurice Hinchey's sta tement that Citigroup was "essentially playing an expensive game of chicken with Congress").

12 See Kane, Banking Powers, supra note 9, at 669. For example, before Citicorp and Travelers filed their merger application, their leaders consulted with and ess entially received advance clearance from FRB chairman Alan Greenspan, Treasury Secretary Robert Rubin and President Clinton. Subsequently, Citigroup, together with other major financial institutions and industry trade groups, reportedly spent $\$ 300$ million (including lobbying expenses and political contributions) to secure passage of the GLB Act. Shortly before Congress passed the GLB Act, Citigroup a ppointed Mr. Rubin as its co-cha irman. Citigroup's representatives also played an active role in negotiations between congressional leaders and the White House over the final terms of the GLB Act. Thus, Citigroup evidently enjoyed a very significant degree of influence over regulat ors and political leaders during the period between its formation and pas sage of the GLB Act. See Arthur E. Wilmarth, Jr., The Transformation of the U.S. Financial Services Industry, 1975-200 0: Competition, Consolidation and Increased Risks, 2002 U. Ill. L. Rev. Issue 2 (forthcoming) [hereinafter cited as Wilmarth, Transformation], Part I(D)(4)(b)(iv).

Indeed, Citigroup was widely viewed as the financial institution that "benefitted the most" from the GLB Act. Barbara A. Rehm, No Merger Wave, But Money Saved, Am. Banker, Nov. 7, 2000, at 1. See also Barbara A. Rehm, How Citi Got Busy to Speed Fed's Merger OK, Am. Banker, July 30, 2001, at 1 (stating that the creation of Citigroup "required significant political muscle" and "spurr[ed] Congress to finally enact sweeping financial reform legislation"). 
to ratify the merger or forcing a potentially disruptive breakup of a huge financial conglomerate. ${ }^{13}$

Although the Citigroup merger and the GLB Act were landmark events, in a broader sense they are byproducts of the fundamental restructuring that has taken place in the U.S. financial services industry over the past quarter century. The dividing lines between banks, securities firms and insurance companies were eroding long before the FRB approved Citigro up's formation and Congress passed the GLB Act. This growing "homogenization" among the three financial sectors was spurred by rapid improvements in information technology, deregulation and financial innovations that broke down traditional barriers between the three sectors.

For example, sophisticated computer systems and new financial instruments (e.g., commercial paper, junk bonds and asset-backed securities) made it feasible to "securitize" many types of business and consumer debt. As a result, many cust omers that previously relied on bank loans gained access to financing from nonbank sources such as finance companies and the public and institutional credit markets. Additionally, advances in information technology and the creation of new financial products enabled aggressive "niche" providers (e.g., credit card banks, discount brokers and mutual fund companies) to offer low-cost cash management and investment management services to the general public. In response to these developments, consumers shifted a rapidly growing share of their investment funds from traditional bank deposits and life insurance policies into mutual funds, variable annuities and other investment vehicles linked to the financial markets.

In combination, these developments caused a dramatic increase in competition and a

13 See Bruce, Citicorp-Tra velers Merger, supra note 6 (citing arguments made by critics of the merger); Fed to Consider Citicorp, Travelers Merger, (New Orleans, LA) Times-Picayune, Sept. 22, 1998, at C5 (same). 
narrowing of profit margins in the markets served by banks, securities firms and life insurance companies. In each of the three financial sectors, incumbent firms encountered declining profits from traditional activities, increased competition from outside entrants, higher risks from new lines of business, and growing pressures to consolidate. Each sector is currently far more vulnerable to financial stress than it was during the early 1970 's. ${ }^{14}$

Large banks, securities broker-dealers and life insurers responded to these trends by pursuing a twofold consolidation strategy designed to defend their existing markets and capture new sources of revenue. First, market leaders within each industry sector sought to enhance their market power by acquiring their traditional competitors. Second, market leaders tried to diversify their activities by acquiring firms in other sectors.

This program of consolidation has trigg ered a wave of mergers within and across the banking, securities and insurance sectors. In the banking industry, a far-reaching consolidation was made possible by (i) new state and federal laws that removed longstanding barriers to geographic expansion, and (ii) lenient antitrust policies adopted by federal bank regulators and the Justice Department. Since 1980, the number of banking organizations has fallen by nearly half and the market share held by the ten largest banks has more than doubled. ${ }^{15}$ Three huge bank

${ }^{14}$ For a detailed analysis of the industry trends described in the foregoing three paragraphs, see Wilmarth, Transformation, supra note 12, Parts I(A) \& (C), II(A) \& (B).

15 See Wilmarth, Transformation, supr a note 12, Part I(D)(1) (describing rapid consolidation within the U.S. banking industry, and reporting that (i) the number of independent U.S. banking organizations declined from 12,500 to 6,800 during 1979-99, and (ii) the percentage of banking industry assets held by the 10 largest banks grew from $23 \%$ to $49 \%$ during 1984-99). The term "banking organization," as used in this chapter, includes each independent bank and each bank holding company that controls one or more banks. Unless the context indicates otherwise, the term "bank" is used to refer to both a chartered bank and a bank holding company. 
mergers were announced in 1998, ${ }^{16}$ and four additional mergers of comparable magnitude were agreed to during 1999-2001. ${ }^{17}$ As a result of this consolidation, the U.S. banking industry is rapidly developing a two-tiered structure. Within the next decade, it appears likely that a small group of very large banks will control most of the industry's assets while the remaining competitors will primarily be community-based institutions or specialized niche providers. Similar patterns of consolidation have occurred within the securities and insurance sectors. ${ }^{18}$

Cross-industry acquisitions have also become important in recent years, as a result of favorable rulings issued by federal banking agencies and the courts. Even before the GLB Act was passed, all of the twenty-five largest U.S. bank holding companies had established subsidiaries engaged in securities underwriting and dealing, and banks had made significant inroads into the insurance business. At the same time, several large securities firms and insurance companies operated conglomerates that competed with each other and with banks over a wide range of financial businesses. ${ }^{19}$ The GLB Act has given further impetus to cross-industry consolidation. During 2000 alone, two large foreign banks acquired major U.S. securities firms, another leading foreign bank purchased a large U.S. insurance company, and Charles Schwab and

16 See id. (discus sing mergers in 1998 between Nations Bank and BankAmerica, Bank One and First Chicago NBD, and Norwest and Wells Fargo).

17 See id. (discussing a merger between Fleet and BankBoston in 1999, and mergers that combined J.P. Morgan with Chase and FirstStar with U.S. Bancorp in 2000); R. Christian Bruce, Fed Clears First Union, Wachovia Deal; Combined Institution Ranks Fourth in U.S., 77 BNA's Banking Rep. 315 (2001).

${ }^{18}$ See Wilmarth, Transformation, supra note 12, Parts I(D)(2), II(C) \& (D).

19 See id., Parts I(E)(2)(a)(i) \& II(C). 
MetLife acquired banks. ${ }^{20}$

Advocates of universal banking contend that the creation of giant financial conglomerates will produce three major benefits: (i) increased efficiency and profitability for financial firms, due to larger economies of scale and scope, (ii) increased safety and soundness for financial firms through a greater diversification of their business lines, and (iii) lower-cost services and improved convenience for consumers based on the concept of "one-stop shopping." doubt whether these optimistic forecasts will be realized. As discussed in Part I of this paper, no domestic or foreign firm has yet realized, on a long-term basis, the theoretical advantages of establishing a "financial supermarket."

In fact, Part I shows that big diversified financial providers have produced a largely disappointing record over the past two decades. Many domestic and foreign financial conglomerates have encountered serious difficulties since the early 1980 's, and several of them have abandoned their efforts to establish universal banks. Similarly, mergers among big banks, or between banks and other financial institutions, generally have failed to produce substantial improvements in efficiency, profitability, shareholder value or customer service. Thus, the experience of the last two decades provides little support for the assumption that financial

${ }^{20}$ See John Tagliabue, Acquisition Highlights Swiss Flair for Managing Expansion, N.Y. Times, Aug. 31, 2000, at C20 (discussing Credit Suisse's acquisition of Donaldson, Lufkin \& Jenrette and UBS' acquisition of PaineWebber); Amy L. Anderson, Sales at Banks A Key Prize In ING Deal For ReliaStar, Am. Banker, May 2, 2000, at 1; Pui-Wing Tam \& Randall Smith, Schwab, Going for High-End Clients, Sets \$2.9 Billion Stock Accord for U.S. Trust, Wall St. J., Jan. 14, 2000, at C1; Lee Ann Gjertsen, MetLife Has Big Plans for One-Branch Bank, Am. Banker, Aug. 17, 2000, at 1.

${ }^{21}$ See, e.g., S. Rep. No. 44, 106th Cong., 1st Sess. 4-6 (1999); James R. Barth, R. Dan Brumbaugh Jr. \& James A. Wilcox, The Repeal of Glass-Steagall and the Advent of Broad Banking, $14 \mathrm{~J}$. Econ. Perspectives 191, 198-99 (2000).; Joao A.C. Santos, Commercial Banks in the Securities Business: A Review, 14 J. Fin. Serv. Res. 35, 37-41 (1998). 
conglomerates will achieve the rosy projections offered by advocates of universal banking.

Doubts about the claimed advantages of universal banks are buttressed by concerns that financial conglomerates will intensify the problem of systemic risk in the financial markets. Over the past two decades, leading banks, securities firms and life insurers have pursued aggressive syndicated lending and securitization programs, as well as speculative underwriting and investment activities in the markets for securities and financial derivatives. These high-risk activities have made large financial institutions vulnerable to serious losses during disruptions in the capital markets. In addition, the growing concentration of securities and derivatives activities within a small group of major financial institutions increases the likelihood that the failure of any big institution could create spillover effects and trigger a costly bailout by federal regulators.

A further threat posed by financial conglomeration is that regulators will feel compelled to prevent the failure of troubled securities firms and life insurers which are affiliated with major banks. Consequently, the federal "safety net" for banks ${ }^{22}$ could be wrapped around entire financial holding companies, thereby undermining the ability of regulators and investors to control the risks of those entities. As discussed in Part II(A) of this paper, domestic and foreign regulat ors are currently revising their policies in an effort to improve capital requirements and enhance supervisory and market discipline over large financial conglomerates. However, Part II concludes that these new regulatory initiatives are unlikely to solve the underlying problems of supervisory forbearance and moral hazard, which are the inevitable corollaries of the "too big to fail” (“TBTF”) policy.

${ }^{22}$ See infra note 43 (discussing the federal "safety net" and suggesting that it confers a substantial net subsidy on banks). 
Part III proposes a new plan for bank regulation and deposit insurance that is designed to counteract the TBTF doctrine's perverse effects. Under this plan, financial conglomerates would be allowed to accept FDIC-insured deposits only within narrow banks, and those banks would be barred from making transfers of funds or credit to affiliates (except for lawful dividends out of profits). The FDIC would be strictly prohibited from paying any uninsured claims when banks fail, and the deposit insurance funds would be completely insulated from the cost of TBTF bailouts. Drawing on its emergency powers as "lender of last resort" ("LOLR"), the FRB would bear primary responsibility for dealing with financial failures involving systemic risk. The FRB would be required to recover the cost of TBTF rescues from financial conglomerates, because those entities are the main beneficiaries of the TBTF doctrine. Three additional recommendations would enhance both regulatory and market-based controls over the risk-taking incentives of universal banks.

\section{Financial Conglomerates Are Not Likely to Produce Their Expected Benefits, and They Will Aggravate Systemic Risk Within the U.S. Economy}

\section{A. The Creation of Big Financial Holding Companies Is Unlikely to Improve Either the Efficiency or the Profitability of the U.S. Financial Services Industry}

Based on the experience of the past two decades, there is little evidence to support the view that large financial conglomerates will perform better than smaller or more specialized financial institutions. Most empirical studies have not found global economies of scale or scope in large diversified banks, full-service securities firms or multiple-line insurance companies. In each sector, the biggest and most diversified firms have consistently produced lower profits and inferior efficiency ratings when compared to smaller or more specialized competitors. Thus, for example, 
(i) smaller regional and community banks and focused cre dit card banks are more efficient and profitable than the largest money center banks, (ii) specialized discount brokers have produced higher returns on equity than full-service broker-dealers, and (iii) specialized life insurers are more efficient than multiple-line insurance companies. ${ }^{23}$

More over, most large mergers among financial firms have failed to produce the "synergies" expected by advocates of consolidation. The great majority of big U.S. bank mergers during the 1990's generated disappointing profits and long-term losses in shareholder wealth. Several of the largest bank mergers during 1996-98 are now widely view ed as costly disappointments or outright failures (viz., Bank One's mergers with First Chicago NBD and First USA, First Union's acquisitions of CoreStates and Money Store, NationsBank's mergers with Barnett Banks and Bank of America, and Wells Fargo's ho stile acquisition of First Interstate). All of the se mergers produced major customer defections, rapid increases in nonperforming loans and large profit shortfalls. The difficulties caused by these mergers, during a period of unprecedented economic expansion, raise troubling questions about the potential problems that could emerge at large consolidated banks if the U.S. economy experiences a severe recession. ${ }^{24}$

Cross-industry diversification has shown no more success than big bank mergers. The “financial supermarkets” created during the 1980's by American Express, GE, Kemper, Prudential and Sears have all been dismantled. Since 1990, AXA, Bankers Trust, Barclays, ING, NatWest

${ }^{23}$ See Wilmarth, Transformation, supra note 12, Parts I(D)(4)(b)(i), II(B)(2), II(C), II(D) \& $\operatorname{III}(\mathrm{A})$.

${ }^{24}$ See id., Part I(D)(4)(a); Ken Brown \& Nikhil Deogun, Heard on the Street: The Incredible Shrinking Bank Premium: Wachovia Deal Illustrates Mood of Caution, Wall St. J., April 17, 2001, at C1 (discussing serious problems encountered by Bank of America, Bank One and First Union after making aggressive acquisitions in the late 1990's); Deal-making done, Economist, Jan. 27, 2001 (same). 
and Security Pacific have either been driven into forced mergers or decided to abandon the capital markets business sector after ambitious expansion plans produced disappointing results. Bank of America's acquisition of Montgomery Securities proved to be an expensive failure, while Conseco's purchase of Green Tree produced huge losses. The most spectacular disaster occurred at Credit Lyonnais, which suffered huge losses after its merchant banking unit, Altus Finance, made risky invest ments in a variety of European and overseas enterprises. The Credit Lyonnais fiasco ultimately forced the French government to finance a \$20 billion rescue plan for the bank. Five big international banks - J.P. Morgan Chase, Citigroup, Credit Suisse, Deutsche Bank and UBS - have continued to pursue a universal banking strategy. However, all five banks have incurred significant losses from capital markets activities at various times in recent years, and even Citigroup cannot yet be declared a long-term success. During the first nine months of 2001, a general slump in the world's equity markets caused sharp declines in earnings from investment banking operations at all five banks. In September, the destruction of the World Trade Center by terrorists inflicted substantial losses on Citigroup's insurance operations and further depressed the earnings of major investment banks. Thus, the diversification strategies implemented by all five banks have exposed them to material risks during disruptions in the financial markets. ${ }^{25}$

${ }^{25}$ For a more detailed discussion of the developments noted in the preceding two para graphs, see Wilmarth, Transformation, supra note 12, Parts I(E)(2)(a)(ii), I(E)(2)(c) \& II(C). For reports of declining profits from investment banking activities at the five leading international banks during the first nine months of 2001, see, e.g., Jathon Sapsford et al., Citigroup, J.P. Morgan Chase and FleetBoston See Earnings Slump, Wall St. J., Oct. 18, 2001, at A4; Liz Moyer, JPM-Chas e, Fleet Feel Pain of Slow Markets, Am. Banker, July 19, 2001, at 1; Liz Moyer et a1., Profits Off, Citi, B of A Brace for More Pain, Am. Banker, April 17, 2001, at 1; Alissa Schmelkin, Credit Suisse Group Profits Tumble 23\%, No Upturn Forecast, Am. Banker, Aug. 30, 2001, at 3; Marcus Walker, Slowdown Grips Deutsche Bank, Profit Falls 49\%, Wall St. J., Aug. 2, 2001, at A10; World Business Briefing Europe: Switzerland: Bank Profit Falls, N. Y. Times, Aug. 15, 2001, at W1 (reporting a 33\% decline in second-quarter profits at UBS). For descriptions of problems caused by the terrorist attack in September, see Paul Beckett et al., Citigroup Joins Firms Warning Of Slim Profits, Wall St. J., Sept. 18, 2001, at A3 (reporting that Citigroup would 
A major reason for the disappointing results of universal banking efforts is that most customers (with the possible exception of very large corporations) have not embraced the concept of "one-stop shopping." Consumers, small businesses and mid-sized firms have expressed a strong preference for diversifying their purchases of financial services among several providers. Customer at titudes help to explain why the "financial supermarkets" of the 1980's failed and why the great financial success stories of the 1990's were focused providers - viz., credit card banks, innovative community-oriented banks, discount brokers and mutual fund managers. Specialized financial firms have earned customer loyalty by providing superior service and/or better investment returns at lower cost. The Internet has greatly enhanced the appeal of specialty firms, because it permits consumers and smaller businesses to make inexpensive nationwide searches for the most attractive combination of price and service. In contrast to these focused competitors, big diversified banks and full-service securities firms have consistently charged higher fees and paid lower returns on deposits or investments. Indeed, one reason to be skeptical about the claimed advantages of "one-stop shopping" in a consolidated financial services industry is that major banks have not delivered on their promises to provide better service and lower prices in a

lose $\$ 700$ million due to insurance claims and the disruption of financial markets); Niamh Ring, Merrill's Cuts Set Off New Talk of Sale, Am. Banker, Oct. 19, 2001, at 2; Emily Thornton, Wall Street: The Big Chill, Bus. Week, Oct. 22, 2001, at 120 [hereinafter cited as Thornton, Wall Street].

Another reason for doubting the long-term success of universal banking is that, since the late 1980's, major European banks have produc ed very disappointing results after acquiring investment banking firms in England and the United States. See Wilmarth, Transformation, supra note 12, Part I(E)(2)(a)(ii); David Fairlamb, All that Glitters . . European banks muff their U.S. buys, Bus. Week, Aug. 13, 2001, at 44; Marcus Walker, Securities Work Taxes European Banks: Earnings Reveal Toll Of Withering Markets On Investment Units, Wall St. J., Aug. 27, 2001, at A10. 
consolidated banking industry. ${ }^{26}$

Three additional factors help to explain why most big banks and other large diversified financial firms in the United States have failed to generate the efficiency and profitability gains predicted by consolidation advocates. First, complex organizational structures and agency conflicts often prevent financial conglomerates from realizing on potential synergies. Second, managers frequently pursue expansion and diversification programs for reasons that have nothing to do with improving customer loyalty or shareholder returns. Managerial hubris and self-interest - particularly the desire to avoid market and regulatory discipline by achieving TBTF status - are powerful motivations behind many big financial mergers. Third, executives must at least pay lip service to "shareholder value" in an age of powerful institutional shareholders. Accordingly, acquiring firms typically issue highly optimistic forecasts about potential cost savings and profit gains when mergers are announced. To achieve these forecasts, acquiring firm managers are tempted to seek higher returns by making drastic cuts in personnel and facilities, pursuing more risky activities and increasing leverage. These aggressive strategies typically alienate customers and produce unexpected losses, often on a very large scale. ${ }^{27}$

${ }^{26}$ See Wilmarth, Transformation, Parts I(D)(2), I(D)(4)(b)(iii) \& II(D). See also Arthur E. Wilmarth, Jr., Too Good to Be True?, The Unfulfilled Promises Behind Big Bank Mergers, 2 Stan. J. L., Bus. \& Fin. 1 (1995) [hereinafter cited as Wilmarth, Big Bank Mergers], at 4-5, 31-41, 87 (contending that, despite optimistic claims made by advoca tes of consolidation, big bank mergers actually produced inferior service and higher prices for consumers and small businesses); Gerald A. Hanweck \& Bernard Shull, The bank merger movement: efficiency, stability and competitive policy concerns, 44 Antitr ust Bull. 251, 258-59, 265-81 (1999) (presenting similar argument); Timothy H. Hannan, Retail Fees of Depository Institutions, 1994-99, 87 Fed. Res. Bull. 1, 8-11 (2001) (reporting that, compared with single-state banks and smaller banks, multistate banks and larger banks charged significantly higher fees on deposit accounts in 1999).

${ }^{27}$ See Wilmarth, Transformation, supra note 12, Parts I(C), I(D)(4)(b), I(E)(1), I(E)(2) \& II(C). See also Matt Murray, Critical Mass: As Huge Companies Keep Growing, CEOs Struggle to Keep Pace, Wall St. J., Feb. 8, 2001, at A1 (reporting that (i) "[m] any of the new behemoths created by [recent] 
In addition to the disappointing record of large financial conglomerates in the United States, it is no teworthy that European universal banks have been less efficient, less profitable and less creative than the top U.S. banks and securities firms over the past three decades. During that period, major U.S. commercial banks have produced higher earnings and maintained better efficiency ratios than the leading French, German and Swiss banks. Similarly, the "big three" U.S. securities firms have dominated European universal banks in the international markets for underwriting securities and advising on corporate mergers and acquisitions.

Most analysts attribute the superior performance of U.S. banks and securities firms to the following factors: (i) U.S. financial firms have faced much more rigorous competition in their home markets, compared to the big European universal banks, and (ii) as a result of this competitive stimulus, U.S. financial firms have produced most of the major financial innovations during the past thirty years, including a broad array of mutual funds, asset-backed securities, overthe-counter ("OTC") derivatives and other creative financial instruments. These American innovations have transformed global finance by encouraging a strong trend to ward (A) replacing intermediated bank credit with capital markets financing, and (B) expanding the use of risk management tools based on sophisticated computer models. ${ }^{28}$

mergers are floundering," including "[a]cquisitive banks like Bank of America Corp. and Bank One Corp.," and (ii) many corp orate CEOs admit that "bigness has become a battle with a new kind of complexity and a new degree of turmoil"); Barbara A. Rehm, Departures: The Goodbye Boys, Am. Banker, Feb. 1, 2001 ("Best in Banking" supplement), at 16A (reporting that, when asked whether a bank can be "too big," former First Union chairman Edward Crutchfield replied: "I don't know. . . . There is no question that size brings benefits. But do they outweigh the downside of being slow, bureaucratic? I'm not sure").

${ }^{28}$ For a more detailed analysis of the comparative performance of U.S. and European financial firms, see Wilmarth, Transformation, supra note 12, Parts I(E)(2)(a)(ii) \& III(A). See also George G. Kaufman, Designing the New Architecture for U.S. Banking, in Benton E. Gup, ED., The New Financial Architecture: Banking Regulation in the 21st Century (2001) [hereinafter cited as New Financial Architecture], at 39 [hereinafter cited as Kaufman, Banking Architecture], at 43-44 
The comparatively poor performance of European universal banks over the past three decades - like the failures of U.S. "financial supermarkets" during the 1980 's - creates substantial doubts whether major financial holding companies will achieve the efficiency and profitability gains predicted by supporters of the GLB Act. Past experience suggests that large, diversified financial organizations (i) will find it very difficult to produce the synergies expected from crossselling, and (ii) will be hampered by managerial diseconomies, agency conflicts and unprofitable cross-subsidies between divisional units. In addition, concerns about the longer-term effects of universal banking have been created by the rapid pace of global consolidation among banks and securities firms and the growing concentration of market power in wholesale financial markets. Continued mergers among major international financial institutions could eliminate most midsized investment banks, thereby reducing competition and innovation in the provision of capital markets services to large corporations. ${ }^{29}$

(stating that U.S. banks have been more profitable than French, German and Swiss banks since 1960); Christos Staikouras, Geoffrey Wood \& Rosie Denney, Bank Non-Interest Income: A Source of Stability?, Feb. 2000 (available at $<$ http://papers.ssrn.com/paper.taf?abstract $\mathrm{id}=233905>$ ), at $8-13$ (including tbls. 3 \& 5) (showing that U.S. banks had a significantly higher average return on ass ets than European banks during the 1990's).

29 See Wilmarth, Transformation, supra note 12, Part III(A). Over the past five years, mergers among domestic and foreign banks and securities firms have created eight global investment banks - viz, the "Big Three" of Goldman Sachs, Morgan Stanley and Merrill Lynch, along with Citigroup, J.P. Morgan Chase, Credit Su isse, Deutsche Bank and UBS. The size and financial resources of those eight firms have caused many analysts to question whether midsized securities firms (e.g., Lehman Brothers and Bear Stearns) can survive as effective competitors. In this regard, a prominent former federal bank regulator has predicted that global consolidation will ultimately produce a dozen financial companies controlling " $85 \%$ of the world's private-sector financial services as sets within 20 years." See Dean Anason, Welcome for Reform Law Gives Way to Uncertainty, Am. Banker, Dec. 16, 1999, at 2 (citing prediction by Eugene Ludwig, Deut sche Bank vice chairman and former Comptroller of the Currency); Randall Smith \& Charles Gasparino, Heard on the Street: Lehman Tries to Thrive as a Solo Player As Mergers Turn Its Rivals Into Goliaths, Wall St. J., Oct. 27, 2000, at C1; Premier investment banks form global giants, 35 Mergers \& Acquisitions No. 9, Oct. 2000, at 13 (stating that "[t]he implications of investment banking consolidation for corpor ate clients have yet to be explored," given "the reduced number of choices they face for [merger 


\section{B. Financial Conglomerates Pose a Significant Potential Threat to the Safety and Stability of the U.S. Finan cial Services Indu stry}

Advocates of universal banking claim that a safer financial system will be created as banks diversify into securities and life insurance activities..$^{30}$ However, there are at least three reasons to question the accuracy of this claim. First, consolidation of the U.S. banking industry during the past two decades has not produced a safer banking system. Second, financial conglomeration is likely to extend the federal "safety net" to include nonbank affiliates of major banks. Third, the GLB Act will promote a greater consolidation of risk within the financial sector, because it has removed the structural separations that (i) previously shielded commercial and investment banks from problems occurring in the other sector, and (ii) enabled each sector to serve as an independent source of financing during financial disruptions.

\section{Consolidation and Increased Risk in the Banking Sector}

Despite predictions that consolidation of the U.S. banking industry would create safer banks that were larger and more geographically diversified, bigger banks have not proven to be safer institutions. Large banks failed at a higher rate than small banks during 1971-91, and excessive risk-taking by large banks posed the greatest threat to the stability of the U.S. banking system during the banking crisis of 1980-92. Several large interstate banks failed or came close to

and acquisition] and corporate finance services").

Rapid consolidation within the syndicated lending market provides another example of the potential adverse effects of mergers and acquisitions on competition in wholesale financial markets. During the past ten years, the top five agent banks increased their collective share of U.S. loan syndications from $26 \%$ to $61 \%$. In a recent survey of corporate finance officers, $72 \%$ of the respondents expressed concern that this consolidation could lead to "monopolistic" pricing for syndicated loans. Jathon Sapsford \& Paul Beckett, Bank Roles: How Consolidation Alters the Field, Wall St. J., April 23, 2001, at C1, C9.

${ }^{30}$ See, e.g., S. Rep. No. 44, supra note 21, at 4-6; Barth, Brumbaugh \& Wilcox, supra note 21, at 198. 
failure during that crisis, because their poorly-managed growth and high-risk lending overwhelmed any advantages provided by geographic diversification. Federal bank regulators granted extensive supervisory forbearance to large troubled banks, and the FRB adopted a highly accommodating interest rate policy in order to rehabilitate those banks in the early 1990 's. ${ }^{31}$

Notwithstanding the painful lessons of the 1980's, big banks resumed their pattern of highrisk behavior almost as soon as they returned to financial health beginning in 1993. During the past several years, major banks have pursued rapid gro wth in risky lines of business tied directly or indirectly to the capital markets - e.g., leveraged syndicated lending, underwriting junk bonds, investing in venture capital projects, dealing and trading in OTC derivatives, and securitizing subprime consumer loans. All of these activities have proven to be vulnerable to sudden disruptions or downturns in the capital markets. At the same time, large banks have artificially boosted their per-share earnings by reducing their capital ratios and loan loss reserves, thereby increasing their vulnerability to adverse economic changes. The current risks facing big banks are reflected in the large losses that several major banks have reported from trading, investing or securitization activities since 1997. ${ }^{32}$ In addition, compared to smaller banks, big banks as a

${ }^{31}$ See Wilmarth, Transformation, supra note 12, Part I(E)(1) (discussing the banking crisis of 1980-92, supervisory forbearance granted to Bank of America and Citicorp after their near-failu res, and the FRB's decision to relax its interest rate policy during the early 1990's). See also Wilmarth, Big Bank Mergers, supra note 26, at 4-6, 41-61, 87 (contending that consolidation failed to produce a safer banking system during 1980-95); Arthur E. Wilmarth, Jr., Too Big to Fail, Too Few to Serve? The Potential Risks of Nationwide Banks, 77 Iowa L. Rev. 957 (1992) [hereinafter cited as Wilmarth, Too Big to Fail], at 98494 (discussing the failure of Bank of New England and the near-failures of Citicorp, C\&S/Sovran and First Interstate during the early 1990's); John Spiege l et AL., Banking Redefined 164-65, 199-200, 210,421 (Irwin Professional Publishing, 1996) (describing the near-failures of Midlantic and C\& S/Sovran, and stating that First Interstate "was almost wiped out by loan losses from acquisitions in Texas and Arizona," id. at 421).

32 See Wilmarth, Transformation, supra note 12, Parts I(C) \& I(E)(2) (discussing (i) higher risks assumed by big banks after 1992, and (ii) large losses from trading, investing or securitization activities 
group have experienced a much more rapid increase in charged-o ff and nonperforming loans during the same period..$^{33}$

Consolidation of the U.S. banking industry thus appears to have promoted an intensification of risk. Over the past three decades, large U.S. banks have shown a consistent pattern of shifting to more aggressive strat egies as they grow in size. Throughout this period, big U.S. banks have operated with significantly higher leverage, less liquidity and a more risky assetliability mix. A recent study of banking systems in twenty-one developed nations found that the U.S. experience is not an isolated phenomenon. This study concluded that the largest banks in these countries engaged in more risky activities and, as a result, faced higher risks of insolvency during 1988-98. ${ }^{34}$

The TBTF doctrine - i.e., the policy of protecting both insured and uninsured depositors in large failing banks - provides the most likely explanation for this correlation between increased

incurred by Bank of America, Bankers Trust and Citigroup during 1998, and by Bank of America, Bank One, J.P. Morgan Chase, FleetBoston, First Union and Wells Fargo during 2000-01).

${ }^{33}$ See R. Alton Gilbert, Problem Business Loans Rise at Large Banks, Monetary Trends, Fed. Res. Bank of St. Louis, MO, Nov. 2000 (available at $<$ www.stls.frb.org $>$ ) (showing that, during 19972000, nonperforming business loans and charge-offs rose at a much more rapid rate among banks that were larger than $\$ 10$ billion). During the first quarter of 2001, three big banks (Bank of America, Bank One and J.P. Morgan Chase) charged off nearly $\$ 2$ billion in bad loans and still held almost $\$ 11$ billion of nonperforming loans at the end of the quarter. See Barbara A. Rehm, It's Bank One, Wells, Fleet in LoanLoss Reserves Derby, Am. Banker, April 27, 2001, at 1.

${ }^{34}$ See Wilmarth, Transformation, supra note 12, Parts I(C), I(D)(4)(b)(iv) \& I(E) (discuss ing higher-risk strategies pursued by large U.S. banks since the 1970's) ; HeNRY KAUFMAN, On MONEY AND Markets: A Wall Street Memoir (2000) [hereinafter Kaufman, On Money and Markets], at 22331, 242-46, 259-68, 278-86, 306-07 (same); Gianni De Nicolo, Size, Charter Value and Risk in Banking: An International Perspective, April 2001, at 3-4, 11-21, 24-25 (available at $<$ http://papers.ssrn.com/sol3/papers.cfm?abstract id $+255465>$ ) (studying the effects of bank size on the operating risk and insolvency risk of publicly-traded banks in 21 developed nations - including the U.S., Japan and major European countries - during 1988-98). 
bank size and greater risk. Between 1972 and mid-1992, U.S. bank regulators protected

uninsured depositors and payments system creditors at every failed bank with assets of more than

$\$ 1$ billion. Federal regulators applied the TBTF policy most prominently in protecting uninsured claimants at Continental Illinois in 1984, First City and First RepublicBank in 1988, MCorp in 1989, and Bank of New England in 1991. Congress effectively codified the TBTF policy in 1991. As a consequence, the rapid consolidation of the U.S. banking industry over the past decade has substantially increased the risk that a major bank failure could bankrupt the FDIC's deposit insurance fund..$^{35}$

${ }^{35}$ Federal regulators officially announced the TBTF doctrine when they rescued Continental Illinois in 1984. In fact, however, regulators had implicitly followed a TBTF policy when they protected uninsured depositors and other creditors at Franklin National Bank in 1974 and First Pennsylvania in 1980. In 1991, Congress provided a statutory basis for TBTF rescues by enacting Section 141 of the Federal Deposit Insurance Corporation Improvement Act ("FDICIA"). Section 141 (codified at 12 U.S.C. $\S$ 1823(c)(4)(G)) authorizes federal regulators to protect uninsured depositors and other creditors in a large failing bank when such action is needed to prevent "serious effects on economic conditions or financial stability." This authority to protect uninsured claimants in a situation involving "systemic risk" is a significant exception to FDICIA's general rule, which bars the FDIC from making payments to uninsured parties that would increase the cost of resolving a failed bank. For a discussion of the TBTF doctrine and Section 141 of FDICIA, see Wilmarth, Transformation, supra note 12, Part I(E)(1).

The collapse of First City in 1992 was the first failure of a bank larger than $\$ 1$ billion in which the FDIC did not give full and immediate protection to all uninsured depositors. See Fed. Deposit Ins. Corp., Managing the Crisis: The FDIC and RTC Experience, 1980-94, at 577-80, 723-25 (Aug. 1998). No U.S. bank larger than $\$ 3$ billion has failed since 1992, and federal regulators therefore do not have a recent track record in applying the TBTF policy. However, many analysts believe that regulators would protect uninsured depositors and payments system creditors if any of the 15 or 20 largest banks were threatened with failure. See, e.g., Ron J. Feldman \& Arthur J. Rolnick, Fixing FDICIA: A Plan to Address the Too-Big-To-Fail Problem, 12 Region No. 1, Fed. Res. Bank of Minneapolis, MN, Mar. 1998, at 2, 69; Wilmarth, Too Big to Fail, supra note 31, at 997-1004; Rob Blackwell, As 'Super Banks' Grow, So Do Analysts' Fears, Am. Banker, Aug. 7, 2000, at 1.

For evidence that consolidation in the U.S. banking indus try has significantly increased the vulnerability of the FDIC's deposit insurance fund, see, e.g., Robert Oshinsky, Effects of Bank Consolidation on the Bank Insurance Fund, FDIC Working Paper No. 99-3 (available at $<$ www.fdic.gov $>$ ), at 2, 12-18 (finding that (i) "the solvency of the [Bank Ins urance Fund ("BIF")] of today is inseparably tied to the health of the largest banking organizations" (id. at 2); and (ii) the failure of any of the 10 largest U.S. banks would create a $12.5 \%$ chance of BIF insolvency); William M. Isaac, Financial Reform's Unfinished 
Studies have shown that the TBTF policy provides a significant implicit subsidy to the largest banks, because (i) it allows big banks to pay below-average interest rates to depositors and other creditors, and (ii) it leads shareholders and uninsured creditors to tolerate lower capital ratios and higher risk profiles at major banks. The risk-taking behavior of big U.S. banks over the past three decades indicates that they fully recognize and exploit their TBTF subsidy. Once again, the relative ineffectiveness of market discipline over big U.S. banks is not a unique experience. For example, a recent study found a strong link between TBTF status and perverse risk incentives among large European banks. ${ }^{36}$

Agenda, 14 Region No. 1, Fed. Res. Bank of Minneapolis, MN, Mar. 2000, at 34, 37 (stating concerns of a former FDIC chairman about the agency's ability to handle the failu re of a giant banking organization like Citigroup, since "Citigroup, at nearly $\$ 800$ billion in size, towers over the \$29 billion FDIC fund").

${ }^{36}$ For the impact of the TBTF doctrine in encouraging greater risk-taking by major U.S. banks, see Wilmarth, Transformation, supra note 12, Parts I(D)(4)(b)(iv), I(E)(1) \& (2) (discussing impact of the TBTF doctrine upon major U.S. banks); Feldman \& Rolnick, supra note 35, at 6-9 (same); KAUFMAN, ON Money And Markets, supra note 34, at 207-10, 226-30, 259-68, 278-86 (same) Edward J. Kane, Incentives for Banking Megamergers: What Motives Might Regulators Infer from Event-Study Evidence?, 32 J. Money, Credit \& Banking 672 (2000) [hereinafter cited as Kane, Megamerger Incentives, at 673-74, 691-94.

For recent studies documenting the implicit subsidy provided to big U.S. banks by the TBTF policy, see, e.g., Craig H. Furfine, Banks as Monitors of Other Banks: Evidence from the Overnight Federal Funds Market, 74 J. Bus. 33, 36-40, 47 (2001) (finding that, during 1998, banks with more than $\$ 10$ billion of a ssets paid significantly lower interest rates on overnight loans than those paid by smaller banks); Hanweck \& Shull, supra note 26, at 274-76 (showing that, in 1997, big banks paid much lower interest rates on deposits and operated with substantially lower equity capital ratios, compared to smaller banks); Donald P. Morgan \& Kevin J. Stiroh, Bond Market Discipline of Banks, in The ChangING Financial Industry Structure and Regulation, at 494, 504-06 (Fed. Res. Bank of Chi., IL, 36th Ann. Conf. on Bank Structure \& Competition, 2000) (conclu ding that, during 1993-98, (i) public bond markets applied much less stringent discipline to banks with assets of more than $\$ 85$ billion, and (ii) weaker bond market discipline was especially evident among the 11 big banks that were publicly identified as TBTF in 1984).

A recent study found that the introduction of mandat ory deposit insurance in the European Union ("EU") in 1995 reduced risk-taking among most EU banks. This risk-reduction effect occurred because, in several EU countries, de jure deposit insurance programs with limited coverage replaced earlier de facto policies of protecting all bank creditors during financial crises. The study concluded that the new EU 


\section{Expansion of the Federal Safety Net}

Mergers among banks, securities firms and insurance companies are likely to extend the scope of the TBTF subsidy to reach nonbank affiliates of large financial holding companies. Although the GLB Act mandates "firewalls" to separate bank subsidiaries from their nonbank affiliates, tho se legal barriers are difficult to enforce and are likely to beco me highly permeable in times of financial stress. During an economic crisis - when investors and creditors are most uncertain about the so undness of financial intermediaries - banks and other financial institutions have a powerful reputational interest in supporting their troubled nonbank subsidiaries, regardless of the formalities of corporate separation. ${ }^{37}$

deposit insurance programs encouraged uninsured depositors and other creditors to monitor the safety and soundness of most EU banks. However, the study also determined that the new EU programs did not reduce risk-taking among banks classified as TBTF (a category including each bank that accounted for more than $12 \%$ of the banking as sets in its country of incorporation). Evidently, uninsured depositors and other creditors of major European banks continued to believe that they would receive full protection, and they therefore did not effectively monitor risk-taking by major banks. Reint Gropp \& Jukka M. Vesala, Deposit Insurance and Moral Hazard: Does the Counterfactual Matter?, European Central Bank Working Paper No. 47, July 2001 (available at <www.ecb.int./pub>), at 2-3, 8-12, 17-24.

37 See Wilmarth, Transformation, supra note 12, Part III(C)(1) (describing the GLB Act's "firewalls" and the practical difficulties inherent in enforcing those restrictions); id. Part III(B)(2) (discussing factors that have caused banks to support their nonbank affiliates); Anthony Cornyn et al., An Analysis of the Concept of Corporate Separateness in BHC Regulation from an Economic Perspective, in Proc eed ings of a Conf. on Bank Structure and Competition 174, 185-93 (Fed. Res. Bank of Chi., IL, 1986) (describing situations in which banks decided to rescue their nonbank affiliates in order to preserve their reputations and avoid a loss of public confidence); Keith R. Fisher, Reweaving the Safety Net: Bank Diversification into Securities and Insurance Activities, 27 Wake Forest L. Rev. 123, 227-31 (1992) (same); Mark J. Flannery, Contagious Bank Runs, Financial Structure and Corporate Separateness within a Bank Holding Company, in Proc eed ings of a Conf. on Bank Structure and Competition 213 (Fed. Res. Bank of Chi., IL, 1986) [hereinafter cited as Flannery, Corporate Separateness], at 217-23 (describing the reputational concerns and fears of "contagion within a holding company" that provide strong incentives for bank holding companies to rescue their troubled nonbank subsidiaries).

During his testimony at a congressional hearing in 1981, W alter Wriston (then chairman of Citicorp) famously declared that "it is inconceivable that any major bank would walk away from any subsidiary of its holding company. If your name is on the door, all of your capital funds are going to be behind it in the real world. Lawyers can say you have separation, but the marketplace is persua sive, and it 
Moreover, in recent years major banks have deliberately increased their reputational stake in nonbank affiliates through market ing campaigns that promote unitary "brand names" covering their ent ire holding companies. The leading U.S. banking or ganizations have also coordinated the activities of their banking and nonbanking subsidiaries by combining banking products with related nonbanking services (e.g., syndicated lending and securities underwriting). As a result, the profits, losses and risks of various units within a financial holding company are likely to be more closely correlated than a comparable group of independent firms. ${ }^{38}$

Accordingly, federal regulators will be inclined to prevent the failure of a nonbank affiliate of a major financial conglomerate, because of concerns that the affiliate's default could trigger a contagious "run" by all of the conglomerate's investors and creditors. Under conditions of widespread economic distress - when financial firms are most vulnerable to a loss of public confidence - regulators would understandably fear that the collapse of a large financial holding company could trigger a systemic "flight to safety" in the financial markets. During financial

would not see it that way." Quoted in Cornyn et al., supra, at 191, 207 n.52.

38 See Flannery, Corporate Separateness, supr a note __, at 214, 223-25; Mark J. Flannery, Modernizing Financial Regulation: The Relation Between Interbank Transactions and Supervisory Reform, 16 J. Fin. Serv. Res. 101 (1999) [hereina fter cited as Flannery, Financial Regulation], at 103-09; Helen A. Garten, Subtle Hazards, Financial Risks, and Diversified Banks: An Essay on the Perils of Regulatory Reform, 49 Md. L. Rev. 314 (1990) [hereinafter cited as Garten, Subtle Hazards], at 346-51, 361-62, 36667, 382; Anthony M. Santomero \& David L. Eckles, The Determinants of Success in the New Financial Services Environment, 6 Econ. Pol'y Rev. No. 4, Fed. Res. Bank of N.Y., Oct. 2000, at 15, 18.

For example, Citigroup recently decided to market all of its global corporate and investment banking services under the brand name of "Citigroup Corporate and Investment Bank." Citigroup executives declared that the new brand name would be "built a round an aggressive, coor dinated advertising and communication plan" that would "bring further clarity to our identity in the marketplace and among our clients." Paul Beckett, So Long, Poker Players: Salomon Is History, Wall St. J., May 23, 2001, at C18 (quoting Michael Carpenter and Sanford Weill). This unified branding strategy certainly increases the likelihood that Citigroup will feel obliged to use the resources of its entire holding company to satisfy future liabilities created by its commercial banking and investment banking subsidiaries. 
disruptions, federal regulators are likely to conclude that they must protect nonbank affiliates of big financial conglomerates in order to reduce the risk of a systemic crisis. ${ }^{39}$

In a recent report, financial regulators from the "Gro up of Ten" developed nations recognized the strong possibility that large financial conglomerates $d o$ create greater "systemic risk" (viz., the risk that the failure of a major financial institution will severely disrupt the financial system and have adverse "spillover" effects on the general economy).$^{40}$ The report pointed to the emergence in the United States of "large complex banking organizations" ("LCBOs"), which engage in a wide range of banking and nonbanking activities and are managed on a highly integrated and centralized basis. The growing consolidation of financial assets within LCBOs has (i) increased the complexity of major financial institutions, making it harder for regulators and market participants to comprehend in a timely manner the risks inherent in LCBOs, (ii) produced

39 See Thomas M. Hoenig, Financial Industry Megamergers and Policy Challenges, 84 Econ. Rev., Fed. Res. Bank of K.C., MO, 3d Qtr. 1999, at 7-8, 10-13 (speech by the Federal Reserve Bank of Kansas City's president); Kaufman, On Money and Markets, supra note 34, at 207, 237-38; Frederic S. Mishkin, Financial consolidation: Dangers and opportunities, 23 J. Banking \& Fin. 675, 680-81 (1999); Santomero \& Eckles, supra note 38, at 15, 18-19 (speech co-authored by the Federal Reserve Bank of Philadelphia's president); Gary H. Stern, Thoughts on Designing Credible Policies After Financial Modernization, 14 Region No. 3, Fed. Res. Bank of Minneapolis, MN, Sept. 2000, at 4-5, 24-25 (remarks by the Federal Reserve Bank of Minneapolis' president); Wilmarth, Transformation, supra note 12, Parts $\mathrm{I}(\mathrm{D})(4)(\mathrm{b})(\mathrm{iv}) \& \mathrm{III}(\mathrm{C})(3)$.

40 See Group of Ten, Report on Consolidation in the Financial Sector, Jan. 2001 (available at $<$ www.bis.org $>$ ) [hereinafter cited as GROUP o F TEN CONSOLIDATION REPORT], at $1 \&$ n. 1 (stating that this report was prepared by staff members of the finance ministries and/or central bank staff of Australia, Belgium, Canada, France, Germany, Italy, Japan, the Netherlands, Spain, Sweden Switzerland, the United Kingdom and the United States, along with representatives of the International Monetary Fund and several other international organizations). "Systemic risk" refers to the risk that (1) the collapse of one or more financial firms will disrupt the financial system by causing failures of other financial institutions (either directly, through defaults on interbank obligations, or indirectly, through a generalized loss of public confidence that results in destabilizing "runs" on other financial institutions), and (2) the disruption of the financial system will impair the general economy by (a) cutting off credit flows to businesses and consumers, and/or (B) causing a sharp depreciation in asset values that increases economic uncerta inty and discourages investment. Id. at 126-27. 
a higher concentration and correlation of credit and market risks among the largest financial institutions, due to their growing domination of the markets for interbank loans, OTC derivatives and investment banking services, and (iii) produced close linkages between banking and nonbanking subsidiaries of financial holding companies, thereby complicating the problem of resolving the failure of a major bank in isolation from its closely linked nonbank affiliates. The report noted that regulators facing the potential failure of an LCBO might well deem it necessary to invoke the "systemic risk" autho rity that permits the FDIC to protect uninsured creditors of a large failing bank. ${ }^{41}$

Similarly, a senior official at Moody's Investors Services, one of the two largest securities rating agencies, has declared that the threat of "financial panic" should cause federal regulators to support big financial conglomerates during "times of extreme financial stress." In his view, the TBTF status of major financial holding companies is undeniable - it is "like the elephant at the picnic - everyone is aware of it, but no one wants to mention it." ${ }^{942}$

In sum, the growth of big financial holding companies increases the likelihood that major

${ }^{41}$ See id. at 132-46. See also Gianni De Nicolo \& Myron L. Kwast, Systemic Risk and Financial Consolidation: Are They Related?, Bd. of Governors of Fed. Res. Sys., Fin. \& Econ. Discussion Ser.

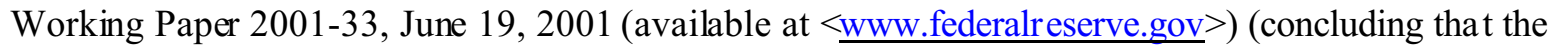
rapidly growing market share held by LCBOs in the U.S. banking industry during 1988-99 probably increased systemic risk, because of closer financial linkages and higher risk correlations among LCBOs); Wilmarth, Transformation, supra note 12, Part I(D)(4)(b)(iv) (discussing the FDIC's authority, under 12 U.S.C. $\S 1823(\mathrm{c})(4)(\mathrm{G})$, to protect uninsured creditors of a bank whose failure could create systemic risk).

${ }^{42}$ Christopher T. Mahoney, Commentary, 6 Econ. Pol'y Rev. No. 4, Fed. Res. Bank of N.Y., Oct. 2000, at 55, 57-58. Federal regulators frequently disclaim any intent to follow a TBTF policy in dealing with the possible failure of a major financial institution. See Kenneth H. Thomas, Fed's 'Too Big to Fail' Stance Curious in the Megabank Era, Am. Banker, July 27, 2001, at 9 (noting statements by FRB chairman Alan Greenspan and vice chairman Roger Ferguson). Nevertheless, Alan Blinder, a former FRB vice chairman, has candidly acknowledged that "[e]verybody knows that there are institutions that are so large and so interlinked with others that it is out of the question to let them fail." Id. 
segments of the securities and life insurance industries will be brought within the scope of the

TBTF doctrine, thereby expanding the scope and cost of federal "safety net" guarantees. ${ }^{43}$ This de facto extension of the federal safety net is likely to be very costly during future financial crises.

For example, during 1980-94, U.S. taxpayers and deposit insurance funds paid out almost \$200

billion to resolve the failures of 3,000 banks and thrift institutions. ${ }^{44}$

The United States has hardly been alone in encountering financial disrupt ions during the

43 The federal "safety net" for banks consists of deposit insurance, protection of uninsured depositors and creditors of big banks under the TBTF policy, dis count window advances provided by the FRB as LOLR, and the FRB's guarantee of interbank payments made on Fedwire. Many regulat ors and analysts have concluded that (i) the federal sa fety net provides a valuable net subsidy to banks (i.e., the safety net confers benefits that exceed the costs of complying with federal bank regulations), and (ii) this subsidy grows much larger in times of financial crisis. The existence of a long-term net subsidy is supported by data showing that financial markets permit banks (especially the largest banks that are pres umptively TBTF) to (A) pay interest rates on deposits that a re substantially lower than market rates paid by nonbank companies on short-term, uninsured debt, and (B) operate with capital ratios that are significantly lower than those held by competing financial intermediaries, such as commercial and consumer finance companies and life insurers. The value of the federal subsidy is also indicated by the fact that no major bank has ever surrendered its charter and chosen to operate as a nonbank. See Allen N. Berger, Richard J. Herring \& Giorgio P. Szegö, The role of capital in financial institutions, 19 J. Banking \& Fin. 393, 400-06 (1995); Frederick Furlong, Federal Subsidies in Banking: The Link to Financial Modernization, FRBSF Econ. Letter No. 97-31, Fed. Res. Bank of S.F., CA, Oct. 24, 1997; Kaufman, On Money and Markets, supra note 34, at 239-40; Myron L. Kwast \& S. Wayne Pas smore, The Subsidy Provided by the Federal Safety Net: Theory and Evidence, 16 J. Fin. Serv. Res. 35 passim (1999); John R. Walter, Can a Safety Net Be Contained?, 84 Econ. Q. No. 1, Fed. Res. Bank of Rich., VA, Winter 1998, at 1, 2-11. See also Olaf de Senerpont Domis, Debunking Debanking. Idea Sounds Interesting But Examine the Costs, Am. Banker, Sept. 29, 1997, at 1, 4 (explaining that a bank which surrendered its charter would lose significant benefits, because (i) an institution without access to the Federal Reserve's payments system would lose "[t]he ability to quickly and efficiently move large amounts of money," and (ii) an institution without depos it insura nce would "[pay] more to attract funds ... [and] would risk losing customers looking for safety").

For a contras ting perspective, questioning whether the federal safety net provides benefits to banks that are greater than the accompanying costs of regulation, see, e.g., Kenneth Jones \& Barry Kolatch, The Federal Safety Net, Banking Subsidies, and Implications for Financial Modernization, 12 FDIC Banking Rev. No. 1, at 1, 2-12 (1999) (agreeing that the federal safety net provides a gross subsidy to banks, but arguing that any net subsidy is small in view of the costs of bank regulation).

${ }^{44}$ See Wilmarth, Transformation, supra note 12, Parts I(E)(1) \& I(E)(2) (b)(iii)(D) (reviewing the costs of resolving bank and thrift failures during 1980-94). 
past two decades. More than 130 countries experienced serious banking problems during 198095, while East Asia and Russia suffered devastating financial crises during 1997-98. Many of these recent financial crises occurred after governments deregulated their financial sectors and failed to exercise adequate supervisory oversight, while continuing to provide explicit or implicit guarantees for bank liabilities. The resulting moral hazard encouraged excessive risk-taking, leading to "boom-and-bust cycles" that ultimately destroyed the solvency of major financial institutions. In addition, most financial crises resulted in costly expenditures of government funds to recapitalize or liquidate failing banks. The United States spent almost 3\% of its gross domestic product ("GDP") in reso lving its thrift crisis, while other count ries have suffered losses ranging from $10-40 \%$ of GDP as a result of financial disruptions. ${ }^{45}$

Thus, the past two decades provide compelling evidence of the dangers inherent in liberalizing the powers of financial institutions without taking adequate steps to remove the moral hazard problems that encourage excessive risk-taking. Recently, Citigroup and Merrill Lynch have demonstrated the ability of large financial conglomerates to exploit the subsidy provided by federal deposit insurance. During 2000, both companies established "sweep" pro grams enabling customers to switch funds from their uninsured securities brokerage accounts into FDIC-insured deposit acco unts at affiliated banks. By April 2001, broker age customers of Merrill Lynch and

45 See, e.g., Ben Bernanke \& Mark Gertler, Monetary Policy and Asset Price Volatility, 84 Econ. Rev. No. 4, Fed. Res. Bank of K.C., MO, 4th Qtr. 1999, at 17, 17-21; Roberto Chang \& Andres Velasco, A Model of Financial Crises in Emerging Markets, 116 Q. J. Econ. 489 passim (2001); Richard J. Herring \& Anthony M. Santomero, What Is Optimal Financial Regulation?, in New Financial Architecture, supra note 28, at 51, 60; George G. Kaufman, Banking and currency crises and systemic risk: Lessons from recent events, 24 Econ. Perspectives No. 3, Fed. Res. Bank of Chi., IL, 3 d Qtr. 2000, at 9 [hereina fter cited as Kaufman, Banking Crises], at 9-20; Kaufman, On Money and Markets, supra note 34, at 5960, 223-46; Michael Moskow, Disruptions in global financial markets: The role of public policy, 24 Econ. Perspectives No. 3, Fed. Res. Bank of Chi., IL, 3d Qtr. 2000, at 2, 2-5. 
Citigroup had used these "sweep" programs to transfer over $\$ 75$ billion into insured deposit accounts. Both companies indicated that their new FDIC-insured deposits would be used, in part, to provide funding for the activities of their nonbank subsidiaries. For example, when a spokesman for Merrill Lynch was asked what his company would do with its "newfound low-cost funds," he replied that the company's deposits would give it "flexibility . . . to finance other parts of our business. ${ }^{946}$

The Citigroup and Merrill Lynch sweep programs also reveal how current banking laws permit large financial conglomerates with multiple bank subsidiaries to expand the level of deposit insurance offered to each customer. Merrill Lynch's brokerage customers can obtain up to $\$ 200,000$ of deposit insurance coverage by making structured transfers to two affiliated banks, while Citigroup's brokerage customers can secure up to $\$ 600,000$ of deposit insurance coverage by making similar transfers to six affiliated banks. Because the banks owned by Merrill Lynch and Citigroup are "well managed" and "well capitalized" under current regulatory standards, both companies receive free deposit insurance for the consumer deposits created by their sweep programs. ${ }^{47}$ Other financial holding companies are likely to establish similar programs, because

46 Richard Melville, Deposit Power: Where Merrill, B of A, Citi Agree, Am. Banker, Dec. 18, 2000, at 1 (quoting James Wiggins of Merrill Lynch, and also reporting that Citigroup was expected to use its deposit sweep program to generate low-cost financing for the consumer lending business of its newlyacquired subsidiary, Associates First Capital). See also Charles Gasparino, Fund Track: Merrill Lynch's Small Investors Face Rate Cut, Wall St. J., April 30, 2001, at C1 (stating that, unlike assets held in its money market mutual funds, Merrill Lynch "can legally lend out its bank deposits, and pocket the interestrate spread between what it pays on the deposits and what it charges investors"); Rob Blackwell, Merrill, Solly Put \$28B Into Insured Accounts, Am. Banker, April 19, 2001, at 1 [hereinafter Blackwell, Deposit Sweeps] (reporting that, as of Mar. 31, 2001, Merrill Lynch's sweep program had created nearly $\$ 60$ billion in new FDIC-insured bank deposits and Citigroup's program had created $\$ 17$ billion of such deposits).

47 See Gasparino, supra note 46; Blackwell, Deposit Sweeps, supra note 46; Wilmarth, Transformation, supra note 12, Part I(C) (explaining that, since 1996, the Federal Deposit Insurance Act 
financial executives and analysts recognize the significant funding advantage provided to banks by their ability to collect low-cost, FDIC-insured deposits. ${ }^{48}$

Financial holding companies will thus have both opportunities and incentives to use their banking subsidiar ies' access to the federal safety net to provide cross-subsidies to their nonbank affiliates. Many analysts have concluded that (i) banks have incentives to transfer a portion of their safety net subsidies to nonbank affiliates, and (ii) while current federal regulations attempt to inhibit such transfers, they cannot prevent them entirely. Transfers of safety net subsidies will inhibit market discipline and encourage greater risk-taking among financial holding companies. Indeed, the risk-enhancing effects of cross-subsidization are likely to offset any risk reduction created by diversification as banks combine with securities firms and life insurance companies. ${ }^{49}$

\section{Greater Consolidation of Risk within the Financial Services Industry}

Perhaps the greatest danger of the movement toward financial conglomeration is that it

("FDI Act") has effectively prevented the FDIC from charging any deposit insurance premiums to "well capitalized" and "well managed" banks, which account for more than $90 \%$ of all U.S. banks).

48 See Steven Pearls tein \& Peter Pae, Megabank Day, Wash. Post, April 19, 1998, at H1 (citing Bank One chairman John McCoy's view that "a ccess to consumer deposits . . . amounted to cheap capital" for big banks); Matthias Rieker, Banks Seen Missing The Boat by Failing to Generate Deposits, Am. Banker, April 5, 2001 , at 2 (reporting that, according to James McCormick of First Manhat tan Consulting Group, consumer deposit a ccounts produced $51 \%$ of total U.S . bank revenues and $66 \%$ of total U.S. bank pretax profits in 1999).

49 See, e.g., Fisher, supra note 37, at 226-30; Garten, Subtle Hazards, supra note 38, at 353-64, 376-81; Jones \& Kolatch, supra note 43, at 12-14; Kane, Megamerger Incentives, supra note 36, at 68994; Walter, supra note 43, at 10-13; GAO Says Banks May Pass Net Subsidy To Their Affiliates, 16 Banking Pol'y Rep. No. 18, Sept. 15, 1997, at 7 [hereinafter cited as GAO Bank Subsidy Report], at 8-9 (reprinting excerpts of letter from GAO Chief Economist James Bothwell to Rep. Richard Baker). See also infra Part II(A)(1) (dis cussing ways in which banks can shift their federal subsidy to affiliates despite the existence of regulatory firewalls); Santomero \& Eckles, supra note 38, at 18-19 (concluding that "universal banking does present a new way in which government-induced moral hazard can manifest itself . . . [and] can be passed down to nonbank subsidiaries owned by universal banks"). 
will increase the concentration of credit risk and market risk within the U.S. financial system. By authorizing unlimited combinations between banks and nonbank financial firms, the GLB Act has largely removed the alternative financing channels that the U.S. financial system contained - and that acted as "shock absorbers" for the U.S. economy - prior to 1999. For example, the FRB mobilized leading U.S. banks to counteract serious disruptions in the capital markets during the Penn Central commercial paper crisis of 1970, the Hunt Brothers silver crisis of 1980, the stock market crash of 1987 and the Russian debt crisis of 1998. In each case, major banks provided emergency credit that enabled large nonbank firms to avoid bankruptcy or severe distress. Banks were able to serve as standby sources of liquidity and credit on each occasion, because their capital markets activities represented a relatively small portion of the ir overall op erations and did not expose them to devastating losses. Conversely, the securities industry provided financing that helped to revive the U.S. economy after the recession and banking crisis of 1990-91, because securities firms were not crippled by the LDC and real estate lending problems that afflicted major banks at that time..$^{50}$ In sum, the legal barriers separating banks and securities firms prior to 1999 reduced systemic risk in the U.S. economy by (i) insulating each sector to a substantial degree from the other's problems, and (ii) allowing each sector to act as an alternative source of financing while the other recovered from serious financial losses. ${ }^{51}$

In contrast, consider the record of Japan during the 1990's. In 1990, the Japanese banking

${ }^{50}$ See Wilmarth, Transformation, supra note 12, Parts I(A)(2)(b), I(E)(2)(b)(iii)(G), and III(B); Remarks by FRB Chairman Alan Greenspan before the World Bank Group and the IMF Program of Seminars, Sept. 27, 1999 (available at $<\underline{w w w . f e d e r a l r e s e r v e . g o v>}>$ ) [hereinafter cited as 1999 Greenspan IMF Speech], at 1-3.

${ }^{51}$ See Kaufman, Banking Architecture, supra note 28, at 44; Wilmarth, Transformation, supra note 12, Part III(B). 
system had massive exposures to both the real estate market and the stock market. Japanese banks made huge amounts of lo ans secured by real estate and securities, and they also held extensive portfolios of corporate stocks, due primarily to cross-shareholding relationships within their respective corporate groups (keiretsu). Beginning in 1990, the Japanese real estate and stock markets both collapsed, with prices in each sector falling by two-thirds or more. Due to staggering losses caused by bad loans and falling stock values, two of the twenty largest Japanese banks failed and several other big banks were driven to the brink of insolvency. Two major securities firms and three large insurance companies also failed. After a decade of hugely expensive programs, the Japanese government has not yet succeeded in its efforts to stimulate the economy and restore the financial system. The Japanese economy has remained stuck in a prolonged slump, due in large part to the inability of banks to provide credit needed by Japanese business firms. Banks are still severely weakened by nonperforming loans and depreciated stocks, and the securities markets have not sustained any prolonged rally. By the autumn of 2001, Japan faced a floundering economy and a fragile banking system, along with record debt levels that made it extremely difficult for the Japanese government to finance new assistance programs. ${ }^{52}$

52 For discussions of the collapse of the Japanese real estate and stock markets since 1990, and the resulting impact on the Japanese economy and financial system, see, e.g., Franklin Allen \& Douglas Gale, Bubbles and Crises, 110 Econ. J. 236, 236-38, 252-54 (2000) Valentine V. Craig, Japanese Banking: A Time of Crisis, 11 FDIC Banking Rev. No. 2, at 9, 12-17 (1998); Curtis J. Milhaupt, Japan's Experience with Deposit Insurance and Failing Banks: Implications for Financial Regulatory Design?, 77 Wash. U. L. Q. 399, 413-24 (1999); Joe Peek \& Eric S. Rosengren, Japanese Banking Problems: Implications for Lending in the United States, New Eng. Econ. Rev., Fed. Res. Bank of Boston, MA, Jan./Feb. 1999, at 25 [hereinafter cited as Peek and Rosengren, Japanese Banking Problems], at 25-31; Wilmarth, Big Bank Mergers, supra note 26, at 62-69.

By the end of 2000, the Japanese government had spent more than $\$ 1$ trillion in its efforts to stimulate the economy (primarily through public works projects and temporary tax cuts). See Bill S pindle, Japan's Massive Debt Bomb Ticks Ever Louder, Wall St. J., Dec. 11, 2000, at A27. In addition, the government had spent more than $\$ 200$ billion, and had budgeted an additional $\$ 350$ billion, to protect bank 
Many observers have blamed Japan's failure to resolve its banking and ec ono mic

problems on the unwillingness of its political and business leaders to push for a fundamental restructuring of Japan's financial system and general econo my. ${ }^{53}$ Resistance to change undoubtedly accounts for a major part of Japan's continuing difficulties. However, the role of Japanese banks as dominant providers of business finance, and their exposure to both credit risk in depositors and recapitalize the banking system. Finally, the government had spent further billions of dollars in "price-keeping operations" designed to support the stock market. See Craig, supra, at 50; Milhaupt, supra, at 421-24; Phred Dvorak \& Peter Landers, Is Japan on the Verge of a Contagious Financial Crisis?, Wall St. J., Mar. 14, 2001, at A14 ("Financial Safety Net" tbl.).

For descriptions of the grave fiscal and economic problems and the unresolved banking crisis that confronted Japan in 200 1, see, e.g., Ken Belson, Japan: This Time, It Could Get Nasty, Bus. Week, Jan. 15,2001 , at 52 (stating that the Japanese government would be "hard-pressed" to finance additional stimulus programs for its struggling economy, because Japan's national debt had already reached $\$ 5.8$ trillion, or $141 \%$ of its gross domestic product, amounting to "the industrialized world's largest fiscal deficit"); Japan's Economy: Another false dawn?, Economist, Mar. 24, 2001, at 79, 80-81 (reporting that (i) Japanese banks had written off about $\$ 600$ billion of nonperforming loans during the prior decade, but they still held that much or more in bad loans on their balance sheets, because "good loans [were] souring as fast as banks can provision against them or write them off," and (ii) while Japanese banks had previously relied on unrealized gains in their "huge equity portfolios" to offset their loan charge-offs, those stock portfolios had become "full of losses" as the Japanese stock market "hover[ed] near a 16-year low"); Phred Dvorak, Corporate Bankruptcies in Japan Hit Record High, Wall St. J., April 16, 2001, at A12 (reporting that Japanese corporations with over \$200 billion in unpaid liabilities had declared bankruptcy during the previous year); Japan's economy: Chronic sickness, Economist, June 2, 2001, at 71,71 (stating that Japan's economy had posted "the worst ten-year performance of any big economy in the past halfcentury"); Japan's banks: Out for the count, Economist, Oct. 11, 2001 (reporting that Japan appeared to be on the brink of a major banking crisis, because a "deepening recession" had caused "bad loans . . . to soar" along with "plunging share prices" that were eroding the capital of Japanese banks).

${ }_{53}$ See, e.g., Craig, supra note 50, at 14-17; Milhaupt, supra note 50, at 408-24; Michael Williams et al., Day of Reckoning: Wall Street Intensifies Japan's Woes, but They All Trace Back to Home, Wall St. J., Mar. 16, 2001, at A1. In June 2001, a new Japa nese government, under the leader ship of Prime Minister Junichiro Koizumi, issued a preliminary outline of structural reforms intended to address Japan's longstanding economic and financial problems. However, analysts questioned whether Mr. Koizumi (i) could overcome well-entrenched opponents of reform among Japan's business leaders, politicians and bureaucrats, and (ii) would retain his political popularity if his reforms, as expected, caused sharp increases in unemployment and corporate bankruptcies. See, e.g., Brian Bremner, Will Koizumi's Reforms Be as Tough as His Talk?, Bus. Week, Aug. 6, 2001, at 45; Clay Chandler, Tokyo Unveils Reform Strategy, Wash. Post, June 22, 2001, at E1; Neil A. Martin, Will Japan's Koizumi Soon Be Ex-Prime Minister?, Barron's, Sept. 10, 2001, at MW10. 
the real estate market and investment risk in the securities markets, help to explain the severity and protracted nature of the Japanese crisis. The Japanese financial system concentrated business financing, credit risk and investment risk within its major banks. As a result, the simultaneous collapse of Japan's real estate and stock markets crippled the banks and left no substantial alternative source of financing for Japanese businesses. ${ }^{54}$

The Japanese experience provides a warning signal about the systemic risk implications of universal banking. Based on merger patterns among domestic and foreign financial institutions since 1990, the GLB Act could spur a consolidation of much of the U.S. banking, securities and life insurance industries into a small group of big universal banks. In addition, as noted above, most financial conglomerates are centrally managed and co ordinate the activities of their nonbank subsidiaries with core operations of their lead banks (e.g., by co mbining securities underw riting with syndicated lending for the same corporate clients). The financial markets and bank regulators therefore view these conglomerates as highly integrated enterprises, despite the GLB Act's mandates for corporate veils and regulatory firewalls between their various subsidiaries. ${ }^{55}$

Thus, the trend toward cross-industry consolidation will increase the concentration and potential correlation of credit risk and market risk in the U.S. financial system. As a result, (i) widespread defaults on bank loans or OTC derivatives will have undermine investor confidence in

54 See Craig, supra note 50, at 9-14; 1999 Greenspan IMF Speech, supra note 48, at 2; Peek \& Rosengren, Japanese Banking Problems, supra note 50, at 26-31; Wilmarth, Big Bank Mergers, supra note 26, at $62-63,69$ n.319.

55 See supra note 38 and accompanying text; Lisa M. DeFerrari \& David E. Palmer, Supervision of Large Complex Banking Organizations, 87 Fed. Res. Bull. 47, 51-53 (2001); Santomero \& Eckles, supra note 38, at 15, 18; U.S. Gen. Accounting Off., Risk-Focus ed Bank Examinations: Regulators of Large Banking Organizations Face Challenges, GAO/GGD-00-48, Jan. 2000 [hereinafter cited as GAO LCBO Study], at 5, 15, 24, 28-30. 
securities firms that are affiliated with banks, and (ii) stock market crashes will have direct spillover effects on banks that are affiliated with securities firms. In short, the growth of large financial holding companies will probably increase the risks of contagion within the financial system, thereby intensifying pressures for TBTF bailouts during financial disruptions. ${ }^{56}$

\section{Current Regulatory Efforts Are Inadequate to Control the Risk-Taking Incentives of Financial Conglomerates}

The current federal supervisory regime attempts to control the risks of LCBOs by pursuing a four-pronged strategy. First, the GLB Act requires financial holding companies to conduct securities, insurance and merchant banking activities in nonbank subsidiaries that are separately incorporated, separately capitalized and insulated by regulatory "firewalls" from their affiliated banks. ${ }^{57}$ Second, the GLB Act declares that all banks in a financial holding company must be "well capitalized," and FDICIA mandates a regime of "prompt corrective action" ("PCA") for any bank that fails to meet prescribed capital standards. ${ }^{58}$ Third, the GLB Act requires all banks in a financial holding company to be "well managed," and the FRB and OCC have instituted new supervisory procedures for evaluating the effectiveness of each LCBO's

${ }^{56}$ See Hoenig, supra note 39, at 10-13; Remarks by FRB Governor Laurence H. Meyer before a Nat'l Bur. of Econ. Res. Conf., Jan. 14, 2000 (<available at www.federalreserve.gov>) [hereinafter cited as 2000 Meyer NBER Speech], at 1-2; Santomero \& Eckles, supra note 38, at 15-16, 18-20; Stern, supra note 39, at 4-5, 24-26. See also Wilmarth, Too Big to Fail, supra note 31, at 986-1004 (contending that large bank mergers create joint failure risks and increase the likelihood of TBTF bailouts).

${ }^{57}$ See S. Rep. No. 44, supra note 21, at 7-8; H.R. Rep. No. 74, 106th Cong., 1st Sess. 133-35 (1999); McCoy, supra note 3, § 6.05; O’Neal, supra note 2, at 100-12.

${ }^{58}$ For a discussion of the GLB Act's provisions, see H.R. Rep. No. 434, 106th Cong., 1st. Sess. 155, 159-60 (1999) (Conf. Rep.); O'Neal, supra note 2, at 104-05, 108, 112 (same). For a discussion of FDICIA's "prompt corrective action" program for undercapitalized banks, see, e.g., George J. Benston \& George G. Kaufman, FDICIA After Five Years, 11 J. Econ. Perspectives 139, 144-49 (1997); U.S. Gen. Accounting Off., Bank and Thrift Regulation: Implementation of F DICIA's Prompt Regulatory Action Provisions, GAO/GGD-97-18, Nov. 1996 [hereinafter cited as GAO PCA Study], at 14-21, 25-27. 
management. ${ }^{59}$ Fourth, Congress and regulators are taking steps to encourage greater market discipline of LCBOs. For example, the GLB Act requires major banks to issue investment-grade debt securities if they wish to establish direct financial subsidiaries. ${ }^{60}$

This regulatory philosophy is consistent with a new capital adequacy proposal issued in January 2001 by the Basel Committee on Bank Supervision. The Basel Committee's 2001 proposal recommends a new regulatory framework based on "three pillars" - minimum capital requirements, enhanced supervisory review procedures and market discipline. As indicated above, these "three pillars" reflect policies that are already being implemented by U.S. bank regulators for LCBOs. ${ }^{61}$ Regarding the first "pillar" of capital requirements, the Basel

59 See H.R. Rep. No. 434, supra note 58, at 155, 159-60 (discussing the GLB Act's "well managed" requirement); O'Neal, supra note 2, at 104-05, 108, 112 (same). For descriptions of the FRB's and OCC's new supervisory procedures for LCBOs, see generally DeFerrari \& Palmer, supra note 55; 2000 Meyer NBER Speech, supra note 56; Remarks by Governor Laurence H. Meyer at the Int'l Banking Conf. of the Fed. Fin. Institutions Examination Council, May 31, 2000 (available at $<$ www.federalreserve.gov $>$ ) [hereinafter cited as 2000 Meyer FFIEC Speech]; GAO LCBO Study, supra note 55 .

${ }^{60}$ See O'Neal, supra note 2, at 109 (explaining provision of GLB Act requiring a national bank to have at least one issue of outs tanding debt securities rated in one of the top three rating categories by a national recognized rating agency if the bank wishes to establish a financial subsidiary and is one of the 50 largest U.S. banks). See also Meyer, NBER Speech, supra note 54, at 2-6 (arguing for measures encouraging greater market discipline over LCBOs; Meyer FFIEC Speech, supra note 59, at 3-4 (same).

${ }^{61}$ See Basel Comm. on Banking Supervision, Overview of The New Basel Capital Accord, Jan. 2001 (available at <www.bis.org $>$ ) [hereinafter cited as 2001 Basel Capital Proposal Overview], at 1,7, 12-36. See also 2000 Meyer NBER Speech, supra note 56, at 2-3 (explaining that federal bank regulators were already implementing sup ervis ory policies that were consistent with the "three pillars" of the Basel Committee's new capital adequacy proposal, as originally set forth in a 1999 concept paper).

In June 2001, responding to widespread criticism of its January proposal, the Ba sel Committee extended its timetable for adopting and implementing its new capital accord. However, the Committee stress ed that "it remains strongly committed to the three pillars architecture of the new Accord and to the broad objective of improving the risk sensitivity of the minimum capital requirements." Basel Comm. on Bank Supervision, Update on the New Basel Capital Accord, 25 June 2001 (available at $<$ www.bis.org $>$ ) [hereinafter cited as June 2001 Basel Update]. See also Richard Cowden \& Daniel Pruzin, Basel Panel Extends Proposal Time Line, Taking Pressure Off Consultation Process, 77 BNA's Banking Rep. 33 
Committee's new proposal incorporates two new approaches that have been pursued by U.S. bank regulators: (i) applying capital requirements on a consolidated basis to the entire financial holding company (including nonbank subsidiaries), and (ii) establishing capital requirements for each LCBO in accordance with internal risk ratings that have been developed by the LCBO's managers and reviewed by bank regulators. ${ }^{62}$

Unfortunately, as discussed below, all four elements of the present U.S. supervisory program for LCBOs have exhibited serious shortcomings in the past. Accordingly, current regulat ory approaches are unlikely to prevent financial conglomerates from engaging in excessive risk-taking at the expense of the federal safety net.

\section{A. The Ineffectiveness of Corporate Separation as a Risk Control Device}

Supervisory requirements based on the concept of corporate separation are in fundamental conflict with the actual behavior of financial holding companies. Most LCBOs operate as unitary enterprises, based on centralized capital allocation and risk management policies that disregard formal structural divisions between corp orate subsidiaries. On many oc casions, financial holding companies have rescued nonbank affiliates or their customers in order to protect the reputations

(2001).

${ }^{62}$ Under the Basel Committee's proposal, only large, sophisticated banks that establish satisfactory internal risk management systems would be permitted to use internal risk ratings to calculate their capital requirements. Smaller banks would continue to comply with uniform, standardized capital rules established by the Basel Committee. See 2001 Basel Capital Proposal Overview, supra note 61, at 12, 7-8, 11-17; 2000 Meyer NBER Speech, supra note 56, at 1-3. See also H.R. Rep. No. 434, supra note 58, at 157-59 (explaining that the GLB Act authorizes the FRB, as "umbrella supervisor," to establish consolidated capital requirements for financial holding companies and their subsidiaries, although the FRB may not change the separate capital rules established by primary regulators for "functionally regulated" subsidiaries, such as banks, securities firms and insurance companies). 
of the parent holding company and its regulated financial institutions.$^{63}$ In the most serious cases, holding company managers have deliberately violated regulatory firewalls by exceeding the legal limits on financial support that banks or other regulated financial institution may provide to troubled affiliates. ${ }^{64}$

The GLB Act relies on Sections 23A and 23B of the Federal Reserve Act to prevent abusive transactions between banks and their nonbank affiliates within the new financial holding company structure ${ }^{65}$ However, regulators and analysts have acknowledged that (i) the restrictions mandated by Sections 23A and 23B are complicated and difficult to enforce, and (ii)

${ }^{63}$ See supra notes 37-38 and accompanying text; Wilmarth, Transformation, supra note 12, Parts $\operatorname{III}(\mathrm{B}) \& \operatorname{III}(\mathrm{C})(1)$.

${ }^{64}$ See, e.g., Cornyn et al., supra note 37, at 186 (describing how Hamilton National Bank failed in the mid-1970's after its parent holding company forced the bank, in violation of legal restrictions on affiliate transactions, to purchase large amounts of low-quality mortgages from its troubled mortgage banking affiliate); Garten, Subtle Hazards, supra note 38, at 353-54 (same, and noting that Continental Bank ignored legal lending limits by extending credit to rescue its options trading subsidiary during the October 1987 st ock market crash); William S. Haraf, The Collapse of Drexel Burnham Lambert: Lessons for the Bank Regulators, Regulation (Cato Rev. of Bus. \& Gov't), Winter 1991, at 22, 23 (stating that, when Drex el Burnham was threatened with failure in early 1990, it withdrew capital from its regulated securities subsidiaries in excess of regulatory limits until the SEC intervened to prevent further capital transfers).

${ }^{65}$ See H.R. Rep. No. 74, supra note 57, at 134-35; Bd. of Governors of Fed. Res. Sys., Transactions Between Banks and Their Affiliates: Notice of proposed rulemaking, 66 Fed. Reg. 24,186 (2001) [hereinafter cited as FRB Proposed Affiliate Transaction Rule], at 24,186.

Section 23A of the Federal Reserve Act prohibits an FDIC-insured bank from engaging in "covered transactions" with nonbank affiliates (e.g., extensions of credit to affiliates or purchases of securities or ass ets from affiliates) in an amount greater than (i) $10 \%$ of the bank's capital stock and surplus for any single affiliate, or (ii) $20 \%$ of its capital stock and surplus for all affiliates. In addition, extensions of credit to affiliates must be secured by qualifying collateral. See 12 U.S.C. $\S \S 371 \mathrm{c} \&$ 1828(j)(1); FRB Proposed Affiliate Transaction Rule, supra, at 24,186-87.

Section 23B generally requires that any transaction between an FDIC-insured bank and a nonbank affiliate must be conducted on terms (including credit standards) comparable to arm's length transactions with non-affiliated companies. See 12 U.S.C. $\S \S 371 \mathrm{c}-1 \& 1828(\mathrm{j})(1)$; FRB Proposed Affiliate Transaction Rule, supra, at 24,187. 
managerial evasions of those provisions are often subtle and hard to detect. As a result, when a financial holding company or some of its subsidiaries are under severe financial stress, regulators may fail to discover and prevent a transfer of bank funds or bank credit that violates regulatory limits. Moreover, to avert a systemic financial crisis, regulators may decide to waive Section 23A and 23B so that major banks can help their troubled affiliates. For example, in September 2001, regulators reportedly suspended Section $23 \mathrm{~A}$ and encouraged leading banks to transfer funds to securities affiliates to head off a threatened liquidity crunch following the terrorist attack on the World Trade Center. ${ }^{66}$

Thus, federal bank regulators currently appear to give little weight to the concept of corporate separation as an effective risk control device. Regulators understand that large financial holding companies operate in accordance with centralized business strategies and risk management systems that transcend corporate boundaries between affiliates. Regulators therefore are now stressing the importance of supervising financial holding companies in a consolidated manner that cuts acro ss corporate divisions among banks subsidiaries and their nonbank

${ }^{66}$ For discussions of the difficulties regulators face in enforcing limitations on affiliate transactions, see Fisher, supra note 37, at 229-30; Garten, Subtle Hazards, supra note 38, at 380-81 (stating that the "[FRB] has admitted that restrictions on interaffiliate funds transfers frequently have been violated or interpreted creatively by management in times of stress"); GAO Bank Subsidy Report, supra note 47, at 8-9. See also infra note 142 and accompanying text (discussing the FRB's reported waiver of Section 23A during September 2001).

In May 2001, the FRB issued proposed and final rules under Sections 23A and 23B that reveal the scope and complexity of legal and operational is sues arising under those statutes. The FRB's proposed rule, which would incorporate most of the interpretations that the FRB has previously issued under those statutes, covers more than 30 pages in the Federal Register. See FRB Proposed Affiliate Transaction Rule, supra note 65. The FRB's final rules, which contain new interpretations of the two statutes, occupy more than a dozen additional pages. See 64 Fed. Reg. 24,220-33 (2001). 
affiliates. ${ }^{67}$ Given the banking agencies' current adherence to the concept of consolidated supervision, I now wonder whether regulators and lobbyists for the financial services industry actually believed in the virtues of corporate separation during the 1990's, or whether they simply used the "firewall" argument to help persuade Congress to enact the GLB Act. ${ }^{68}$

\section{B. Shortcomings in Capital Regulation}

Federal regulators first adopted across-the-board capital rules for banks in 1981-83.

Those rules imposed fixed leverage requirements based on balance sheet assets but did not account for off-balance-sheet obligations (e.g., standby letters of credit, loan commitments and derivatives) held by banks. As a result, many banks reduced their effective regulatory capital requirements by shifting from traditional lending to the issuance of off-balance-sheet commitments that often carried equal or greater credit risks. ${ }^{69}$

During 1989-92, federal regulators implemented the international risk-based capital accord

${ }^{67}$ See, e.g., DeFerrari \& Palmer, supra note 55, at 51-53; GAO LCBO Study, supra note 55, at 5, 7, 14-18, 24-30; Meyer FFIEC Speech, supra note 59, at 5-8.

${ }^{68}$ See, e.g., S. Rep. No. 44, supra note 21, at 7 (concluding that the holding company structure would ensure that the FDIC's deposit insurance funds were "adequat ely insulated from paying the losses of firms which are affiliated with insured banks"); H.R. Rep. No. 74, supra note 57, at 99-102 (citing statements by federal regulators and industry representatives claiming that corporate separation and regulatory "firewalls" would insula te FDIC-insured banks from the potential risks of their nonbank affiliates). See also Flannery, Financial Regulation, supra note 38, at 112 n.10 (stating that "many proponents of broad financial conglomerate powers insist that legal separateness will effectively insulate banking activities, without explicitly addressing the question of de facto integration. This omission is particularly noteworthy when it is accompanied by an assertion that regulation should permit conglomerates to take maximum advantage of scope economies among the various product lines - which seems to contradict the promise of de facto separateness!').

69 Between 1984 and 1989, the off-balance-sheet activities of banks increased from 55\% of on-balance-sheet assets to $164 \%$ of such assets. This rapid growth of off-balance-sheet commitments "effectively decreas ed capital" at many banks. U.S. Gen. Accounting Off., Deposit Insurance: A Strategy for Reform, GAO/GGD-91-26, Mar. 1991 [hereinafter GAO Deposit Insurance Reform Study], at 84-85. See also Berger, Herring \& Szegö, supra note 43, at 419-20. 
promulgated by the Basel Committee in 1988 (the "1988 Accord"). The 1988 Accord establishes minimum capital requirements for banks by assigning various types of loans and off-balance-sheet commitments to four risk-weighted categories based on perceived credit risks. The 1988 Accord has thus removed the prior regulatory incentive for off-balance-sheet commitments, but its four risk-weighted categories are too broad and imprecise to distinguish among similar types of assets with very different degrees of credit risk. For example, a loan to a "blue chip" corporation with a triple-A credit rating carries the same $100 \%$ risk weight under the 1988 Accord as a loan to a speculative company with a below-investment grade rating. ${ }^{70}$ The 1988 Accord's unsophisticated treatment of credit risk has enabled LCBOs to engage in "capital arbitrage" by (i) using complex derivatives, whose embedded risks are difficult to value, as substitutes for conventional financing arrangements, and (ii) structuring securitizations that transfer low-risk assets out of the bank while retaining more risky assets (including residual interests in securitizations). ${ }^{71}$

The 1988 Basel Accord also did not take account of the market risk of derivatives, securities and other trading assets held by banks. In response to rapid increases in trading activity at large banks during the early 1990's, the Basel Committee adopted supplemental capital rules for

${ }^{70}$ See Berger, Herring \& Szegö, supra note 43, at 414-15; GAO Deposit Insurance Reform Study, supra note 69 , at $85-88$.

${ }^{71}$ See Robert C. Merton, Financial innovation and the management and regulation of financial institutions, 19 J. Banking \& Fin. 461, 468-70 (1995) (showing how a bank could greatly reduce its effective capital requirements under the 1988 Accord by using derivatives in place of conventional financial instruments); Wilmarth, Transformation, supra note 12, Part I(E)(2)(e)(iv) (ex plaining how large ba nks have used securitization techniques to engage in "capital arbitrage" that significantly reduces their capital requirements under the 1988 Accord). See also U.S. Gen. Accounting Off., Risk-Based Capital: Regula tory and Indu stry Approaches to Capital and Risk, GAO/GGD-98-153, July 1998 [her einafter cited as GAO Risk-Based Capital Study], at 68, 169 (reporting that, in discus sions with representatives of six major banks, "[o]fficials of two banks commented that they are not constrained by regulatory capital requirements, because assets can always be securitized so capital will not have to be held against them, or they can move to riskier assets in each credit risk category to obtain higher returns"). 
market risk in early 1996, and those rules were promptly implemented by federal bank regulators. The capital rules for market risk require large banks with significant trading assets to establish their capital requirements based on internal risk models that measure their "value at risk," or VAR, subject to periodic reviews by federal regulators. ${ }^{72}$ The Basel Committee's 2001 proposal would extend this supervisory trend to ward reliance on internal risk management by allowing qualifying banks to use internal risk ratings for loans in calculating their capital requirements for credit risk and operational risk. ${ }^{73}$

As the foregoing summary indicates, federal regulators have repeatedly adjusted their capital rules over the past two decade in an effort to discourage banks from taking excessive risks. However, capital rules have not proven to be a sufficient safeguard. Past banking crises have shown that capital is a "lagging indicator" of bank problems, because declines in capital are frequently not reported until banks have already become seriously troubled. ${ }^{74}$ One reason for this time lag is that many assets held by banks (e.g., commercial loans, OTC derivatives and residual interests in securitizations) are not traded on any organized market and are therefore very difficult for regulators and outside investors to value. Accordingly, outsiders frequently do not identify

${ }^{72}$ See GAO Risk-Based Capital Study, supra note 71, at 49-53; Joao A.C. Santos, Bank Capital Regulation in Contemporary Banking Theory: A Review of the Literature, Bank for Int'l Settlements Working Paper No. 90, Sept. 2000 (<available at www.bis.org $>$ ), at 18, 21.

73 See 2001 Basel Capital Proposal Overview, supra note 61, at 7-10, 17-29; D. Johannes Jüttner, Message to Basle: Risk Reduction Rather Than Management, in New Financial ArChitecture, supra note 28 , at 207, 208-09, 217-18.

${ }^{74}$ See, e.g., Geoffrey P. Miller, Das Kapital: Solvency Regulation of the American Business Enterprise, in Eric A. Posner, ed., Chicago Lectures in Law and Economics (Foundation Press, 2000), at 65 [hereinafter cited as Miller, Solvency Regulation], at 78; Joe Peek \& Eric S. Ros engren, The Use of Capital Ratios to Trigger Intervention in Problem Banks: Too Little, Too Late, New Eng. Econ. Rev., Sept./Oct. 1996, at 49 [hereinafter cited as Peek \& Rosengren, Capital Ratios], at 50-52, 56-57; GAO Deposit Insurance Reform Study, supra note 69, at 61. 
problems of asset depreciation and reductions in capital until significant damage has already occurred. Moreover, managers of a troubled bank are inclined to postpone any writedowns of assets and capital in the hope that they can improve the bank's situation before its next supervisory examination or required public disclosure to investors. ${ }^{75}$

FDICIA's PCA regime was designed to strengthen the effectiveness of capital regulation and to discourage superviso ry forbearance. FDICIA requires bank regulat ors to schedule yearly examinations for most banks (including all large banks), and it also compels regulators to take a series of pro gressively more stringent enforcement measures if a bank falls below the "adequately capitalized" standard or below two lower capital thresholds. ${ }^{76}$ However, federal regulators weakened the effectiveness of PCA by choosing a lenient capital adequacy test. Virtually all banks met this "adequately capitalized" standard when the PCA rules took effect in 1992, even though the banking industry was just emerging from a major crisis. ${ }^{77}$ It appears that federal regulators deliberately chose a low capital threshold for PCA because many large banks could not have met a higher standard during the early 1990 's. ${ }^{78}$ Studies have confirmed that PCA's

75 See, e.g., Berger, Herring \& Szegö, supra note 43, at 411-16, 425; Jeffrey W. Gunther \& Robert R. Moore, Financial Statements and Reality: Do Troubled Banks Tell All?, Econ. \& Fin. Rev., Fed. Res. Bank of Dallas, TX, 3d Qtr. 2000, at 30; Peek \& Rosengren, Capital Ratios, supra note 74, at 51, 57; GAO PCA Study, supra note 58, at 43-44.

${ }^{76}$ See Benston \& Kaufman, supra note 58, at 144-48; GAO PCA Study, supra note 58, at 14-21.

77 See GAO PCA Study, supra note 58, at 26-28 \& tbls. $2.1 \& 2.2$ (stating that (i) banks are deemed "adequately capitalized" under the PCA rules if they have (A) Tier 1 capital equal to $4 \%$ of riskbased assets and $4 \%$ of total assets, and (B) total capital equal to $8 \%$ of risk-based assets; and (ii) more than $98 \%$ of all banks and thrifts satis fied this "adequately capitalized" standard at the end of 1992). See also Benston \& Kaufman, supra note 58, at 146-48 (contending that federal regulators set the "adequately capitalized" threshold too low); Peek \& Rosengren, Capital Ratios, supra note 74, at 57 (same).

78 See GAO Deposit Ins urance Reform Study, supra note 69, at 85-87, 91 (stating that, as of September 1990, (i) $96 \%$ of all banks met the $8 \%$ total risk-based capital requirement for "adequately 
"adequately capitalized" threshold would not have identified most troubled banks during the 1980 's, and that the standard was also too low to capture most problem banks during the mid1990 's. ${ }^{79}$

In short, the capital adequacy test that triggers supervisory intervention under PCA is "an unreliable indicator of insolvency risk." ${ }^{\text {" }}$ The regulators' selection of a low capital "tripwire" for PCA creates serious doubts about whether they would return to a policy of supervisory forbearance if they were confronted with a systemic crisis involving the potential failure of several large banks. The recent failure of Superior Bank raises additional questions about the effectiveness of PCA, because regulat ors failed to recognize or resp ond to the severity of the bank's problems until its capital was already deeply impaired by losses resulting from its high-risk subprime lending and securitization activities. ${ }^{81}$

capitalized" status under the 1988 Accord, but (ii) 56\% of all banks larger than $\$ 1$ billion would have failed to meet the total risk-based capital standard if it were raised to $10 \%$ ). The GAO was not satisfied with the 1988 Accord's capital standards, finding that they were "too low to adequately compensate for the types of risks that exist in today's highly competitive banking environment." Id. at 87.

79 See David S. Jones \& Kathleen K. King, The implementation of prompt corrective action: An assessment, 19 J. Banking \& Fin. 491, 493, 498-99, 508 (1995) (finding that, due to the lenient capital adequacy test established by regulators, PCA rules would not have applied to the "vast majority" of troubled banks even if those rules had been in force during the 1980's); Peek \& Rosengren, Capital Ratios, supra note 74 , at 52-56 (reaching the same conclusion). See also GAO PCA Study, supra note 58, at $45 \&$ tbl. 3.1 (finding that, during 1992-95, more than four-fifths of problem banks met the "adequately capitalized" test and therefore were not subject to mandatory enforcement measures under the PCA rules). 74 , at 57 .

${ }^{80}$ Jones \& King, supra note 79, at 495. Accord, Peek \& Rosengren, Capital Ratios, supra note

${ }^{81}$ See Benston \& Kaufman, supra note 58, at 146-49, 152-56; GAO PCA Study, supra note 58, at 5-7, 25-29, 41-49, 55-56; Bd. of Governors of Fed. Res. Sys. \& U.S. Treas. Dept., The Feasibility and Desirability of Mandatory Subordinated Debt, Dec. 2000 [hereinafter cited as Federal Subordinated Debt Study], at ix.

Superior Bank, a federally-chartered thrift with assets of $\$ 2.3$ billion, failed in July 2001 after the bank's capital had been wiped out by a decline of more than $\$ 500$ million in the value of the bank's 
Another continuing problem with capital regulation is the ability of LCBOs to engage in “capital arbitrage." As discussed above, large sophist icated banks have repeatedly reduced their effective capital requirements by exploiting gaps in regulatory capital rules. Big banks shifted to off-balance-sheet commitments to evade the simple leverage requirements of the 1980's, and they implemented large-scale securitization programs to exploit the risk-based rules established under the 1988 Accord.$^{82}$ Two recent studies have confirmed that higher regulatory capital requirements failed to eliminate high-risk bank strategies during the early 1990's, especially among larger banks. ${ }^{83}$ Thus, the experience of the past two decades indicates that capital regulation "is inevitably imperfect in its application and encourages all sorts of regulatory avoidance measures." ${ }^{94}$

residual interests resulting from its securitization of $\$ 4$ billion of subprime loans. As the FDIC acknowledged, Superior's failure "illustrates the limits of [PCA] tools given to regulators," because PCA sanctions are ineffective when regulators fail to recognize losses embedded in unmarketable assets, like securitization residuals, whose worth depends on "complex, assumption-driven" valuation models. Statement of FDIC Director John Reich on the Failure of Superior Bank, FSB, submitted to the Senate Comm. on Banking, Housing and Urban Affairs, Sept. 11, 2001 (available at $<$ www.fdic.gov/news/speeches/chairman/sp11sep01.html $>$ ), at 1. See also Rob Blackwell, Failure of Superior Turns Quickly Into Blame Game, Am. Banker, July 31, 2001, at 1; Rob Blackwell, Does Superior Prove S\&L Reforms a Flop?, Am. Banker, Aug. 20, 2001, at 1.

${ }^{82}$ See supra note 69 and ac companying text (discussing widespread instanc es of capital arbitrage by major banks).

${ }^{83}$ See Tina M. Galloway, Winson B. Lee \& Dianne M. Roden, Banks' changing incentives and opportunities for risk taking, 21 J. Banking \& Fin. 509, 513-15, 521-23 (1997) (finding that, during 199094, stricter federal regulations "did not appear to have a significant impact on risk-taking behavior" by banks that had low charter values and "high risk-taking incentives"); Armen Hovakimian \& Edward J. Kane, Effectiveness of Capital Regulation at U.S. Commercial Banks, 1985 to 1994, 55 J. Fin. 451, 452, 461-64 (2000) (finding that (i) during 1992-94, stricter federal rules "curtailed but did not eliminate riskshifting incentives" by weak banks that sought to "extract a deposit insurance subsidy," id. at 464, and (ii) "the effectiveness of regulatory discipline declines as banks grow larger," id. at 461).

${ }^{84}$ Miller, Solvency Regulation, supra note 74, at 78. See also 2000 Meyer FFIEC Speech, supra note 59, at 2-3 (stating that (i) bankers "will arbitrage" whenever they believe that regulatory capital requirements exceed their own view of needed economic capital "by more than the cost of arbitrage," and 
The Basel Committee and federal bank regulators are attempting to grapple with these shortcomings in capital regulation for LCBOs by shifting from uniform rules to an individualized approach that relies on internal risk management policies developed by each LCBO. However, this effort to base capital requirements on LCBOs' internal risk ratings is a highly problematic move. Bank credit scoring models failed to anticipate the surge in consumer defaults on cre dit card loans that occurred during 1996-97. Similarly, "Value-at-Risk" ("VAR") models developed by J.P. Morgan and other leading banks did not predict the severe trading losses that occurred during the global financial market disruption triggered by Russia's debt default in $1998 .{ }^{85}$ Studies have shown that the most widely-used bank models for estimating market risk and credit risk are unreliable, because (i) they are based on faulty assumptions and insufficient data, and (ii) they permit banks to pursue strategies that may prove to be disastrous, because they tolerate a lowpercentage risk of catastrophic losses. ${ }^{86}$ Another glaring problem is that conventional risk models

(ii) "regardless of [regulatory] actions, frontier banks will always attempt to manage their businesses to earn competitive risk-adjusted rates of return on equity") (emphasis in original).

${ }^{85}$ See Jeremy Berkowitz \& James O’Brien, How Accurate Are Value-at-Risk Models at Commercial Banks?, Bd. of Governors of Fed. Res. Sys., Fin. \& Econ. Discussion Ser., Working Paper 2001-31, July 2001 (available at <www.federalreserve.gov/pubs/feds/2001>), at 3-5 (finding that VAR models for trading activities at six major U.S. banks failed to anticipate large trading losses during the 1998 disruption in world financial markets, as the models' predictions of maximum possible losses were "blown out" by the losses actually incurred); Wilmarth, Transformation, supra note 12, Parts $\mathrm{I}(\mathrm{E})(2)(\mathrm{b})(\mathrm{iii})(\mathrm{C}), \mathrm{I}(\mathrm{E})(2)(\mathrm{c})$ \& I(E)(2)(e)(iii)(B) (discussing shortcomings in VAR and credit scoring models developed by J.P. Morgan and other large banks).

${ }^{86}$ For analysis of the questionable methodologies underlying the market risk and credit risk models used by major banks, see Wilmarth, Transformation, supra note 12, Part I(E)(2)(b)(iii)(C) (dis cussing major flaws in bank models for market risk); Patricia Jackson \& William Perraudin, Regulatory implications of credit risk modelling, 24 J. Banking \& Fin. 1 (2000) (discussing various problems with bank models for credit risk and concluding that "capital requirements bas ed directly on credit risk models are simply not a practical possibility in the near future"); Robert A. Jarrow \& Stuart M. Turnbull, The intersection of market and credit risk, 24 J. Banking \& Fin. 271, 272-78 (2000) (discussing serious problems with the "standard methodologies for credit risk management" used at most banks, id. at 273); 
evaluate market risk and credit risk in isolation from each other, contrary to abundant evidence showing that "market and credit risk are intrinsically related to each other and ... are not separable. ${ }^{97}$

The Basel Committee's 2001 proposal "stop[s] short" of allowing banks to establish their capital requirements based on "full [internal] credit risk models." Nevertheless, the proposal would allow each qualifying bank to use internal risk ratings in estimating the probability of default by borrowers and the banks' exposure to loss in the event ofdefault. ${ }^{88}$ Analysts have questioned, however, whether most large banks have reliable internal risk management systems to calculate even these more limited measures of credit risk and their potential correlations across

Jüttner, supra note 71, at 208-19 (same); Frank Partnoy, The Siskel and Ebert of Financial Markets? Two Thumbs Down for the Credit Rating Agencies, 77 Wash. U. L. Q. 619, 660-61 (1999) (stating that "even the most sophisticated current methods of analyzing credit risk are seriously flawed").

Other studies conclude that VAR models used by regulators to determine capital requirements for market risk create a perverse incentive for banks. These VAR-based capital rules penalize banks that exceed a defined risk threshold on more than $1 \%$ of trading days during a 250 -day trading period. However, the VAR rules do not as sess any additional penalties based on the magnitude of losses that a bank may incur during those "outlier" days. Because the VAR rules focus on the frequency rather than the magnitude of tra ding losses, the rules encourage profit-max imizing banks to construct risky asset portfolios that may produce larger gains but also tolerate a low-percentage risk of catastrophic losses. See Gordon J. Alexander \& Alexandre M. Baptista, A VaR-Constrained Mean-Variance Model: Implications for Portfolio Selection and the Basle Capital Accord, Working Paper, July 16, 2001, passim (available at $<$ http://papers.ssrn.com/sol3/papers.cfm?abstract id=275894>); Suleyman Basak \& Alexander Shapiro, Value-at-Risk-Based Management: Optimal Policies and Asset Prices, 14 Rev. Fin. Stud. 371, 372-80, 385, 398-99 (2001).

${ }^{87}$ See Jarrow \& Turnbull, supra note 86, at 272 (quote), 273-77, 292-93; Jüttner, supra note 73, at 218-19, 223-25.

88 See 2001 Basel Capital Proposal Overview, supra note 61, at 8 (quote), 17-23; Speech by FRB Governor Laurence H. Meyer before the Institute of Int'1 Bankers, May 5, 2001 (<available at www.federalreserve.gov $>$ ) [hereinafter cited as Meyer IIB Speech], at 4-5, 7-8. 
entire loan portfolios. ${ }^{89}$

A more fundamental problem is that bank regulators and bankers have sharply conflicting motivations in establishing capital standards. Regulators and bankers have a shared interest in choosing a capital level that will allow banks to earn profits and avoid a clear risk of insolvency. Beyond this common interest, however, the goals of regulators and bankers diverge significantly. Regulat ors want conservative capital rules that discourage imprudent risk-taking and protect the federal sa fety net, even at the expense of constraining bank profits. In cont rast, bankers want liberal capital rules that permit higher leverage and a greater ability to exploit the federal safety net subsidy, because those circumstances create the potential for higher shareholder returns. Accordingly, it is very doubtful whether federal regulators can rely on bankers to incorporate supervisory concerns in their internal risk management process. ${ }^{90}$ Bankers would clearly have a strong incentive to manipulate their internal risk rating systems to reduce their effective capital requirements. $^{91}$

In this regard, it is very troubling that the Basel Committee's 2001 proposal offers LCBOs the opportunity to reduce their capital requirements if they establish internal rating systems for

${ }^{89}$ See Howell E. Jackson, The Role of Credit Rating Agencies in the Establishment of Capital Standards for Financial Institutions in a Global Economy (undated working paper on file with the author) [hereinafter cited as Jackson, Role of Credit Rating Agencies], at 9-15; Jüttner, supra note 73, at 208-22; John J. Mingo, Policy implications of the Federal Reserve study of credit risk models at major US banking institutions, 24 J. Banking \& Fin. 15, 25-29 (2000). 71 , at 94 .

90 See GAO LCBO Study, supra note 55, at 41-42; GAO Risk-Based Capital Study, supra note

91 See GAO Risk-Based Capital Study, supra note 71, at 96-98. See also Jackson, Role of Credit Rating Agencies, supra note 89, at 15 (questioning "how much regulatory author ities should delegate the establishment of capital standards to bank management," since "the reason why we regulate bank capital requirements in the first place is the belief that left to their own devices banks will maintain less capital than is socially desirable"). 
credit risk. The proposal essentially guarantees that banks with qualified internal rating systems will receive lower capital requirements than banks who se capital levels are determined under the Committe e's "standardised approach" for credit risk. The Basel Committee thus appears to be inviting LCBOs to develop internal rating systems for the specific purpose of reducing their capital. ${ }^{92}$ This approach hardly seems consistent with recent evidence indicating that major banks do $n o t$ hold sufficient capital and reserves in light of their inherent risks. ${ }^{93}$

A further problem with the Basel proposal is that regulators may not possess sufficient expertise to understand and critique the internal risk management systems developed by LCBOs. Regulators generally cannot compete with major financial institutions in hiring highly-paid financial "rocket scientists" to design and analyze complex derivatives and other sophisticated risk management tools. Accordingly, regulators may not be able to verify, with a high degree of confidence, the internal risk models and ratings developed by financial conglomerates. ${ }^{94}$

Finally, the new supervisory strategy of basing capital requirements on internal risk management raises the issue of how to deter LCBOs from deliberately or negligently reducing their capital below a level that is reaso nably needed to ensure their solvency. A few years ago, the

92 See 2001 Basel Capital Proposal Overview, supra note 61, at 9 (stating that, as an incentive for banks to develop internal ratings-based approaches, the proposal provides "capital incentives [for the internal ratings-based approach] relative to the standardised approach"); June 2001 Basel Update, supra note 61 (confirming that the proposed new capital accord would give "capital incentives ... to encourage banks to adopt these more advanced approaches to credit risk"). See also Meyer IIB Speech, supra note 88 , at 5, 7-8, 10 (stating that banks qualifying for the internal ratings-based approach would have "lower total regulatory capital charges" and could experience "a significant decline in capital requirements relative to current levels").

93 See Wilmarth, Transformation, supra note 12, Part I(C) (discussing analysts' and regulators' concerns about insufficient bank capital and reserves).

94 See Kaufman, On Money and Markets, supra note 34, at 225-29; GAO LCBO Study, supra note 55, at 7, 48; GAO Risk-Based Capital Study, supra note 71, at 98-99. 
FRB considered a "precommitment" approach, under which LCBOs would commit to maintain adequate capital based on their int ernal risk management systems and would pay fines if their capital alloc ations proved to be inadequate to meet their actual risks. However, this "precommitment" approach was not adopted, and analysts have questioned whether regulators would actually be willing to impose penalties that were large enough to deter LCBOs from manipulating their internal risk calculations. As critics noted, major banks are most likely to suffer capital shortfalls during periods of severe economic strain, and regulators would understandably be reluctant under those conditions to enforce large fines that might threaten the solvency of troubled LCBOs. ${ }^{95}$ Unfortunately, the BaselCommittee's 2001 proposal does not suggest any reliable mechanism for discouraging LCBOs from using aggressive methods of internal risk measurement as a new form of capital arbitrage. ${ }^{96}$

\section{Current Limitations on Supervisory and Market Discipline}

Bank supervision and market discipline share a common goal of discouraging banks from taking excessive risks. Recent studies have shown that examinations by regulators and market discipline by investors, analysts and credit rating ag encies play complementary roles in res training

95 See Jackson \& Perraudin, supra note 86, at 11-12; GAO Risk-Based Capital Study, supra note 71, at 110-1 1. In 1996, the New York Clearing House conducted a one-year test in which 10 major banks each precommitted an amount of capital for market risk based on its internal risk models. None of the 10 banks incurred trading losses that exceeded its precommitted capital during the one-year test period. It should be noted, however, that (i) the precommitted capital amounts were less than the levels that would have been required under the existing capital rules for market risk, and (ii) the test occurred during a period of relative calm in the financial markets. While this test was too short to provide a reliable evaluation of the precommitment approach, it did suggest that LCBOs are likely to reduce their capital levels if they are permitted to rely on internal risk models. See id. at 112-13.

${ }^{96}$ Cf. Mingo, supra note 89, at 17-18 (warning that "the pace of financial innovation is such that simply recognizing the act of [regulat ory capital arbitrage ("RCA")] is often quite difficult. . . The sheer complexity and diversity of RCA, coupled with the limited budgets of supervisory agencies, make rapid discovery of RCA impractical, if not impossible"). 
risk-taking by banks. It appears that differing oversight methods used by regulators and market observers enable each group to discover proprietary information about banks that is not readily available to the other group. ${ }^{97}$

Nevertheless, both bank regulat ors and the securities markets have often failed to identify problems at major financial institutions until those institutions were already seriously or fat ally injured. For example, federal regulators, credit rating agencies and investors did not recognize severe weaknesses at many large banks during the 1980's (including Continental Illinois and Bank of New England) until those banks were dangerously close to failure. ${ }^{98}$ Federal regulators also failed in 1998 to perceive the grave threat that Long-Term Capital Management ("LTCM") posed to leading banks and securities firms, as well as the financial markets generally, until the hedge fund revealed its perilous condition to the FRB-NY. ${ }^{99}$ Credit rating agencies did not anticipate the failure of several large insurance companies in the early 1990's, or the Orange County bankruptcy

${ }^{97}$ See, e.g., Allen N. Berger, Sally M. Davies \& Mark J. Flannery, Comparing Market and Supervisory Assessments of Bank Performance: Who Knows What When?, 32 J. Money, Credit \& Banking 641 (2000); Robert DeYoung et al., The Information Content of Bank Exam Ratings and Subordinated Debt Prices, 33 J. Money, Credit \& Banking 900 (2001); Bd. of Governors of the Fed. Res. Sys., Staff Study 172, Using Subordinated Debt as an Instrument of Market Discipline, Dec. 1999 [hereinafter cited as FR B Staff Subor dinated Debt Study], at 5, 12-15 (reviewing studies evaluating the comparative effectiveness of regulators and market participants in disciplining banks).

98 See Benton E. Gup, Market Discipline and the Corporate Governance of Banks: Theory vs. Evidence, in New Financial Architecture, supra note 28, at 187 [hereinafter cited as Gup, Market Discipline], at 195-99 (describing failures by regulators and investors to anticipate bank failures); Howell E. Jackson, The Expanding Obligations of Financial Holding Companies, 107 Harv. L. Rev. 509 (1994) [hereinafter cited as Jackson, Holding Company Obligations], at 597 (stating that "the [credit] ratings services ... have not done a particularly good job at anticipating bank failures"); Richard E. Randall, Can the Market Evaluate Asset Quality Exposure in Banks?, New Eng. Econ. Rev., Fed. Res. Bank of Boston, MA, July/Aug. 1989, at 3 (concluding that investors, stock analysts and bond rating agencies all failed to identify serious asset problems at 40 large banks during the 1980's until after substantial damage had occurred); Wilmarth, Too Big to Fail, supra note 31, at 992 (citing studies with similar findings).

99 See Wilmarth, Transformation, supra note 12, Parts I(E)(2)(b)(iii)(D), (E) \& (G). 
in late 1994, or the defaults of several subprime consumer finance companies in 1997. ${ }^{100}$ Most securities analysts expressed surprise when First Union and Wells Fargo publicly disclosed the disastrous results of their mergers with CoreStates and First Inters tate, respectively. ${ }^{101}$

In the international arena, the IMF, bank regulators, credit rating ag encies and investors all failed to anticipate the onset, severity and contagious effects of the Mexican peso crisis of 199495 and the Asian and Russian crises of 1997-98. ${ }^{102}$ Similarly, regulators, banks and investors did not comprehend the potential risk exposures of major U.S. banks to tho se foreign crises. The former co-chairman of Citigro up recently ackno wledged that major banks, in spite of their co stly investments in risk management, failed to foresee major shocks to the global financial system during the 1990 's, and he candidly acknowledged that "we don't do very well in managing risk in the financial sector." ${ }^{103}$

100 See Partnoy, supra note 86, at 661-62, 665.

101 See Rick Brooks, How Bad News of First Union Caught Many Analysts Napping, Wall St. J., May 28, 1999, at C1; Valerie Block, Sense of Betrayal on Wall St. After Wells Surprise, Am. Banker, July 21,1997 , at 1 .

102 See, e.g., Jeffrey E. Garten, Lessons for the Next Financial Crisis, 78 Foreign Affairs No. 2, Mar./April 1999, at 76, 76-83; Reuven Glick, Thoughts on the Origins of the Asian Crisis: Impuls es and Propagation Mechanisms, in William C. Hunt er e t al., eds., The Asian Financial Cris is: Origins, Implications and Solutions (Kluwer Academic Pub., 1999) [hereinafter cited as Asian Financ ial CRISIS], at 33, 33-38, 47-51; Gup, Market Discipline, supra note 98, at 199-201; Jüttner, supra note 71, at 215-17; Kaufman, On Money And Markets, supra note 34, at 281 -86; Karin Lissakers, The IMF and the Asian Crisis: A View from the Executive Board, in Asian Financial Cris is, supra, at 3, 4-7; David Mars hall, The crisis of 1998 and the role of the central bank, 25 Econ. Perspectives No. 1, Fed. Res. Bank of Chi., IL, 1st Qtr. 2001, at 2, 7 (stating that "[t]he Asian crisis was completely unforeseen by financial markets").

103 Tom Fernandez, Reed Warns: Banks Not Equipped for Crisis, Am. Banker, Feb. 14, 2001, at 2 (quoting John Reed). See als o Gup, Market Discipline, supra note 98, at 199-201; Hovakimian \& Kane, supra note 81, at 451 (stating that "the nation's 100 largest banks lost a lmost one-fourth of their market capita lization during the third quarter of 1998," thereby indicating that "risk-modeling systems for managing bank and taxpayer loss exposure are less effective than advertised"); Osman Kilic, David Tufte \& M. Kabir Hassan, The 1994-95 Mexico Currency Crisis and U.S. Bank Stock Returns, 16 J. Fin. Serv. 
Three primary factors appear to explain these repeated failures in supervisory and market discipline of LCBOs. First, major banks have become more complex and harder to evaluate by regulat ors and the financial markets over the past three decades. Second, all of the three leading external sources of discipline for large banks - securities analysts, rating agencies and bank regulators - are compromised to a substantial degree by conflicting interests and goals. Third, while market discipline is frequently ineffective in predicting the onset of financial crises, it can be indiscriminate in punishing firms after a financial crisis begins. As a consequence, regulators have consistently opposed any strong form of market discipline, based on their fear that investors will engage in mass "flights to safety" during economic crises and thereby undermine the stability of financial markets.

\section{The Growing Complexity and Opacity of Financial Conglomerates}

Big banks have increasingly specialized over the past three decades in providing loans to borrowers whose financial condition and future prospects cannot be readily assessed by the securities markets. Improvements in information technology and financial innovations have enabled the securities markets to underwrite debt securities for a broader range of issuers, thereby forcing large banks to shift their commercial lending focus to more risky and opaque firms. As a result, regulators and financial markets find it increasingly difficult to comprehend the risks embedded in bank loan portfolios. ${ }^{104}$

Res. 47, 57-59 (1999) (finding that the Mexic an peso cris is was "surprising to tra ders" and caused significant volatility in the stock prices for big banks that had major lending exposures to Mexico); infra notes 107-08 and accompanying text (discussing studies finding that investors failed to anticipate serious problems at large U.S. banks during 1975-94).

104 See supra note 14 and accompanying text; Wilmarth, Transformation, supra note 12, Parts I(A) \& I(E)(2)(a)(iii) \& (d). 
Major banks have also increased their opacity to regulators and the securities markets by expanding their dealing and trading activities involving securities and OTC derivatives. Like bank loans, OTC derivatives are privately-neg otiated, customized financial instruments whose terms and potential financial impact are largely unknown to outsiders. ${ }^{105}$ OTC derivatives and complex, option-based securities enable banks (i) to place highly-leveraged bets on the direction of interest rates, currency rates and market pric es for commodities, bonds and stocks, and (ii) to make rapid and fundamental changes in their risk exposures. As a result of this new financial technology, it is extremely hard for regulators and market participants to evaluate the current financial condition of major banks. At the same time, financial conglomer ates are creating new correlations among interest rate risk, credit risk and market risk as they combine traditional lending operations with investment banking and insurance activities. Neither regulators nor market participants are well positioned to assess the potential dangers of these new risk correlations. ${ }^{106}$

Three recent studies demonstrate the relative opacity of major banks to the financial markets. One study found that investors did not anticipate either dividend cuts or regulatory enforcement actions at seventeen big "money center" banks during 1975-92. Public announc ements of both types of events caused sharp, immediate declines in the stock prices of the

105 See id., Parts I(A)(1), I(E)(1) \& I(E)(2)(b) (discussing "opaque" nature of bank loans and OTC financial derivatives). See also Partnoy, supra note 86 , at 676-81 (describing credit derivatives as "among the most exotic, fastest growing, and perhaps most problematic segment of the derivatives market," id. at 676, and explaining that "a risk buyer [under a credit swap] can increase its exposure [to credit risk] without increasing the size of its balance sheet," id. at 677).

106 See, e.g., Flannery, Financial Regulation, supra note 38, at 101-03, 105-09; KAUFMAN, ON Money And Markets, supra note 34, at 71-83, 281-86, 329-37; Meyer FFIEC Speech, supra note 59, at 1, 5-6; Santomero \& Eckles, supra note 38, at 15, 18; Alfred Steinherr, Derivatives: The Wild Beast of Finance 252-65, 274-84 (1998); Steven A. Seelig, Banking Trends and Deposit Insurance Risk Assessment in the Twenty-First Century, in New Financial Architecture, supra note 28, at 129, 13140. 
subject banks. In addition, public disclosures of dividend cuts had significantly negative contagious effects on the stock prices of other "money center" and regional banks. ${ }^{107}$ A second study concluded that public reports of Bankers Trust's legal problems in 1994 with disgruntled OTC derivatives clients had a significantly adverse impact on Bankers Trust's stock price as well as the stock prices of thirteen other banks that were leading dealers in OTC derivatives. ${ }^{108}$ Both studies indicate that the financial markets did not comprehend the potential risk exposures of major banks until their problems were publicly disclosed.

Finally, a third study determined that, during 1983-93, Moody's and Standard \& Poor's had greater disagre ements in their bond ratings for banks and insurance companies than for any other type of firm. In addition, the rating agencies' disagreements over bond ratings for banks increased after 1986, notwithstanding the efforts of Congress and bank regulators to restrict the scope of the TBTF policy. Donald Morgan, the study's author, concluded that the largest banks became less transparent to credit rating agencies after 1986 as those banks increased their focus on trading in securities, OTC derivatives and other financial instruments. The rating agencies apparently found it difficult to assess the risks inherent in bank trading positions that changed rapidly and without timely notice to market participants. The high concentrations of loans held by big banks also increased their opacity, because the rating agencies could not readily measure

107 See Myron B. Slovin, Marie E. Slushka \& John A. Polonchek, An anlysis of contagion and competitive effects at commercial banks, 54 J. Fin. Econ. 197 (1999).

108 See Joseph F. S inkey, Jr. \& David A. Carter, The reaction of bank stock prices to news of derivatives losses by corporate clients, 23 J. Banking \& Fin. 1725 (1999). 
the creditworthiness of the borrowers. ${ }^{109}$

\section{Conflicting Inte rests and Objectives among Outside Monitors}

The effectiveness of the principal outside monitors for LCBOs - financial analysts, credit rating agencies and regulators - is undermined to a substantial degree by their conflicting incentives and goals. Financial analysts have become more lenient in their assessment of large banks in recent years, due to the employment of most leading analysts by major securities firms. Wall Street firms obviously want to sell investment banking service s to major banks, and investment bankers within those firms have therefore brought intense pressure on their analyst colleagues to issue favorable investment reports for leading banks. Indeed, securities firms have dismissed several prominent analysts who expressed bearish or critical opinions about big banks. ${ }^{110}$

Similarly, the independence and reliability of cre dit ratings have declined as rating

109 See Donald P. Morgan, Rating Banks: Risk and Uncertainty in an Opaque Industry, Fed. Res. Bank of N.Y., Staff Reports No. 105, May 2000 (available at <www.ny.frb.org $>$ ). See also Morgan \& Stiroh, supra note 36 , at 504-06.

110 See, e.g., Gup, Market Discipline, supra note 98, at 201; Jeffrey M. Laderman, Wall Street's Spin Game, Bus. Week, Oct. 5, 1998, at 148; Tom Lauricella, Deals \& Deal Makers: Analyst Reports Pressures of Employer's Trading, Wall St. J., Sept. 4, 2001, at C1. See also Liz Moyer, Prudential Contrarian Turns Sour on Banks, Am. Banker, Mar. 9, 2001, at 20 (reporting that Michael Mayo, after reportedly being dismis sed by Credit Suis se for bearish calls on major banks, joined Prudential Securities and felt free to issue "sell" recommendations for nine banks, because Prudential had closed down its investment banking unit and instituted a new policy of "offering 'objective' stock analysis untainted by the demands of in-house investment bankers").

In June 2001, the Securities Industry Association issued voluntary guidelines for "best practices" designed to protect the independence and objectivity of securities analysts. However, members of Congress and analys ts sharply criticized these guidelines as being inadequa te to cure the structural conflicts of interest inherent in major Wall Street firms. See, e.g., Rob Garver, Baker, Oxley on SIA Guidelines: Not Enough, Am. Banker, June 15, 2001, at 4; Emily Thornton, Commentary: Wall Street's Chinese Walls Aren't Strong Enough, Bus. Week, Aug. 27, 2001, at 56. 
agencies have gained the power to issue "regulatory licenses" to bond issuers. Rules adopted by federal and state regulators since 1975 have greatly restricted the ability of banks, mutual funds and insurance companies to purchase debt securities that do not carry investment-grade ratings from nationally-reco gnized rating agencies. Issuers are willing to pay substantial fees to the designated rating agencies to earn high ratings, because those ratings serve as de facto regulatory licenses and permit the sale of bonds to institutional investors. ${ }^{111}$

Professor Frank Partnoy contends that these regulations "have fundamentally changed the nature of the product rating agencies sell. Today, issuers are paying rating fees, not to purchase credibility with the investor community, but rather to purchase a license [to sell bonds] from the regulators." As a result, rating agencies focus primarily on the opportunity to earn lucrative fees from bond issuers, instead of making costly investments to protect their reputation for accurate ratings. Rating agencies have concluded that they can "maintain whatever credibility they need by parroting market price moves," since it is "easy to follow market events and adjust ratings after the fact." ${ }^{112}$

The unfortunate results of these changed incentives for rating agencies are that (i) bond ratings have become "lagging indicators of credit quality," and (ii) the rating agencies have

111 See Partnoy, supra note 86, at 623-24, 681-83, 688-703. See also Lawrence J. White, The Credit Rating Industry: An Industrial Orga nization Analysis, N.Y.U. Ctr. for Law \& Bus. Working Paper No. 01-001, April 20, 2001 (available at $<$ http://papers.ssrn.com/paper.taf?abstract id=267083>), at 5, 10-14, 23-24.

112 Partnoy, supra note 86, at 703. See also id. at 651-54, 681-82 (contending that, by virtue of their ability to sell "regulat ory licenses," the nationa lly-recognized rating agencies operate under "oligopolistic" conditions that enable them (i) to "earn abnormal profits" by charging large fees to issuers, (ii) to make modest investments in their credit review operations, including the payment of below-avera ge salaries to their analysts) (quotes at 682); White, supra note 111, at 10-19, 23-25 (reaching similar conclusions). 
become subject to increased pressure to provide high ratings to powerful issuers. ${ }^{113}$ Given these developments, some analysts have criticized proposals (including the new Basel capital adequacy proposal) that would rely on credit ratings of borrowers in determining capital requirements for banks under the "standardised approach" for calculating credit risk. These analysts fear that using credit ratings as a supervisory tool could intensify the pressures on rating agencies - from borrowers, banks and even regulators - to provide favorable ratings for important borrowers, especially during times of financial stress. ${ }^{114}$

Bank regulators also have conflicting goals that often lead them to adopt a policy of supervisory forbearance toward LCBOs. Despite their policy interest in preventing moral hazard, regulators have a personal reputational interest in postponing the recognition of big bank failures so that a major, well-publicized disaster will not occur "on their watch." In addition, during financial crises, regulators are strongly influenced by their fear that a major bank failure could trigger a systemic panic within the financial system. ${ }^{115}$ This regulatory dilemma was vividly illustrated during the banking crisis of 1980-92, when regulators consistently chose to rescue (or at least post pone the failure) of big banks. In structuring bailouts of First Pennsylvania and Continental Illinois, in postponing the failures of First RepublicBank and Bank of New England, and in providing extensive forbearance to Bank of America and Citicorp, regulators repeatedly demonstrated their preference for maintaining financial stability. There is little doubt that the

113 See Partnoy, supra note 86, at 659 (quoting Prof. Bruce Lehmann), 662.

114 See id. at 659; Jackson, Role of Credit Rating Agencies, supra note 89, at 16-18; White, supra note 111 , at 1, 31-32.

115 See, e.g., Kane, Megamerger Incentives, supra note 36, at 689-94; Santomero \& Eckles, supra note 38 , at 18-19; Stern, supra note 39 , at 3, 24-26. 
regulat ors' accommodating treatment of TBTF institutions increased moral hazard and risk-taking among large banks. ${ }^{116}$

The emergence of bank-centered financial conglomerates during the 1990's, and the GLB Act's explicit blessing for those conglomerates, will almost certainly intensify the TBTF problems that afflicted bank regulators during the 1980-92 crisis. Most analysts ass ume that regulat ors will not allow a big universal bank or any of its significant subsidiaries to fail. This assumption finds support in the FRB's aggressive actions to stabilize the financial markets following the Russian debt crisis of 1998, when the FRB (i) organized the rescue of LTCM to prevent a failure that could have created serious "spillover" effects for several major financial institutions, (ii) arranged the sale of a deeply-troubled Bankers Trust to Deutsche Bank, and (iii) orchestrated three rapid cuts in short-term interest rates to restore liquidity and confidence in the financial mark ets. The FRB's 1998 actions - particularly when viewed against the background of its similar stabilizing actions during the 1970 Penn Central crisis, the 1980 Hunt silver crisis and the 1987 stock market crash - have created strong expectations that federal regulat ors will intervene to prevent the failure not only of big banks but also of major nonbanking firms whose default could threaten the solvency of large banks or the stability of the financial markets. ${ }^{117}$ Such expectations obviously

116 See James R. Barth, R. Dan Brumbaugh, Jr. \& Robert E. Litan, The Future of Americ An BAnKing 21-57, 65-79, 89-94, 110-16, 160-62 (1992); John H. Boyd \& Mark Gertler, The Role of Large Banks in the Recent U.S. Banking Crisis, 18 Q. Rev. No. 1, Fed. Res. Bank of Minneapolis, MN, Winter 1994, at 2 passim; Wilmarth, Too Big to Fail, supra note 31, at 994-1002; Wilmarth, Transformation, supra note 12, Parts I(D)(4)(b)(iv) \& I(E)(1).

117 See, e.g., Kane, Megamerger Incentives, supra note 36, at 673-74, 691-94; KaUfMan, ON Money AND MARKETS, supra note 34, at 206-10, 226-30, 237-38, 280-86; Marshall, supra note 102, at 26, 13-15; Santomero \& Eckles, supra note 38, at 18-19; Wilmarth, Transformation, supra note 12, Parts $\mathrm{I}(\mathrm{A})(2)(\mathrm{b}), \mathrm{I}(\mathrm{D})(4)(\mathrm{b})(\mathrm{iv}) \& \mathrm{III}(\mathrm{B})$. 
undermine the incentives of creditors to monitor and control risk-taking by large financial conglomerates. ${ }^{118}$

\section{Limitations on the Effectiveness of Market Discipline as a Risk Control Device for Universal Banks}

\section{a. The Inconsistency of Market Discipline}

The reliability of market discipline as a risk control device is also limited by the fact that financial markets often appear to be ineffective in predicting the onset of economic crises and indiscriminate in punishing risky firms after crises occur. Recent studies have shown that market discipline fluctuates in its intensity, with more relaxed monitoring in good times and more stringent oversight during periods of financial stress. The varying intensity of market discipline is exemplified by the tendency of investors to act with excessive optimism during an expansionary "bubble" and to panic when the "bubble" bursts. For example, during the mid-1990's, financial institutions and other investors from developed nations disregarded potential warning signs and made huge investments in Latin America, Asia and Russia. However, when subsequent events revealed the full risks of those investments, foreign investors engaged in frenzied "flights to safety" that had a devastating impact on developing economies. The crises of the 1990's, like

earlier "boom-and-bust cycles" in domestic and foreign economies since 1970, show how difficult it is for market participants and regulators (i) to avoid an excessive expansion of credit and speculative activities during the "bubble" phase of an economic boom, and (ii) to prevent a

118 See, e.g, Flannery, Financial Regulation, supra note 38, at 102, 107-08; KAUfMAN, ON Money \& MARKeTS, supra note 34, at 208-10, 226-28, 238-40; Stern, supra note 39, at 4, 24-27. 
liquidity crisis in the financial markets and a sharp contraction in credit after the "bubble" bursts. ${ }^{119}$

The information technology and telecommunications sectors experienced a similar "boomand-bust cycle" in the United States and Europe during 1996-2001. Investors bid up the stocks of high-technology companies to stratospheric levels during the bull market of the late 1990's. During the same period, banks, venture capital funds and other institutional investors provided abundant debt and equity financing to Internet and telecommunications ventures. By the spring of 2000, however, it became evident that (i) the "new economy" would not continue to grow at the rapid pace of the 1990's, and (ii) Internet and telecommunications firms could not meet their optimistic forecasts for revenues and earnings, because they had created operating capacity that far exceeded near-term cust omer demand for their services. As financial markets recognized the magnitude of these adverse develo pments, investors sold off shares of high-tech companies and the markets for initial public offerings, junk bonds and bank loans virtually shut down for Internet and telecommunications firms.

Between March 2000 and July 200 1, the NASDAQ stock market lost $60 \%$ of its value and high-tech sto ck markets in Europe fared even worse. Unfortunately, the damage caused by the bursting of the Internet "bubble" was not confined to high-technology sectors. The Internet "bust" trigg ered a genera lized slowdown in U.S. and European economies and posed a significant threat to the health of major financial institutions. By the fall of 2001, some analysts warned that

119 See, e.g., Allen \& Gale, supra note 52, at 236-40, 247-54; Bernanke \& Gertler, supra note 45, at 17-21; Chang \& Velasco, supra note 45; Kaufman, Banking Architecture, supra note 28, at 46-47; Kaufman, Banking Crises, supra note 43, at 11-18; Kaufman, On Money And MARKets, supra note 34, at 68-83, 201-25, 270-325; Marshall, supra note 102, at 2-8, 13-15; Robert J. Shiller, Irrat ional EXUBERANCE 96-132, 203-33 (2000). 
financial institutions with heavy exposures to syndicated loans and junk bonds could face losses comparable to those suffered by the banking and thrift industries during the 1980 's. ${ }^{120}$

The foregoing evidence indicates that market discipline does not exert a consistent restraining force on managerial risk-taking. Investors are prone to engage in periodic cycles of euphoria and panic, due in part to their uncertainty about the direction of the economy and the soundness of financial intermediaries. ${ }^{121}$ These cycles of investor sentiment are evident in the banking industry as well as the general economy. Studies of recent banking crises in the United States and Latin America have concluded that investors and depositors (i) failed to restrain risktaking by bank managers until a financial crisis revealed that their institutions had already suffered severe harm, (ii) typically reacted to a crisis in the short term by punishing all banks exposed to the crisis, with only a limited degree of discrimination among banks with differing risk exposures, and (iii) applied a more effective and discriminating form of discipline only after the crisis had passed. ${ }^{122}$ Benton Gup has summarized the historical record of market discipline as a risk control

${ }^{120}$ For discussion of the events discussed in the two preceding paragraphs, see, e.g., Franklin Allen, Do Financial Institutions Matter?, 56 J. Fin. 1165, 1168-71 (2001); ShILler, supra note 119, at 341; Rebecca Blumenstein et al., Downed Lines: Telecom Sector's Bust Reverberates Loudly Across the Economy, Wall St. J., July 25, 2001, at A1; Michael J. Mandel, Commentary: In a One-World Economy, a Slump Sinks All Boats, Bus. Week, June 25, 2001, at 38; A global game of dominoes - The world economy, Economist, Aug. 25, 2001 (Special Rep.) (retrieved through LEXIS-NEXIS); Germany's Neuer Markt: Penny bazaar, Economist, July 21, 2001 (retrieved through LEXIS-NEXIS); Lea Paterson, Lessons from history may help America to recover, The Times (London, UK), Oct. 2, 2001 (retrieved through LEXIS-NEXIS); William C. Symonds et al., Corporate America Braces for the Shakeout, Bus. Week, Oct. 15, 2001, at 44; Heather Timmons, Feeling the Telecom's Pain: Insurers and Banks, Bus. Week, April 23, 2001, at 110; Thornton, Wall Street, supra note 25.

121 A discussion of psychological factors that may contribute to investor euphoria or panic is beyond the scope of this work. For recent discussions of these factors, see, e.g., David Hir shleifer, Investor Psychology and Asset Pricing, 56 J. Fin. 1533 passim (2001); Shiller, supra note 119, at 135-232.

122 See, e.g., Randall, supra note 98, at 4, 7-14, 18 (finding that equity investors failed to perceive serious problems at 40 large U.S. banks during the 1980's until severe damage had already occurred); John 
device as follows:

[B]ank regulat ors hope that market discipline will aid them in their task of bank supervision. This chapter quest ioned the effectiveness of market discipline. The track record of market discipline examined here suggests that it usually occurs after a significant incident, and that it does little to prevent misbehavior. . . . If market discipline means survival of the fittest, it works. If market discipline means controlling behavior, it does not appear to be effective. ${ }^{123}$

Notwithstanding this cautionary evidence regarding the limitations of market discipline, several prominent analysts have argued that a mandatory subordinated debt program for LCBOs would effectively control managerial risk-taking and supervisory forbearance. Under this approach, LCBOs would be required to issue subordinated debt on a frequent and continuing basis in order to satisfy a designated portion of their capital requirements. According to proponents of market discipline, holders of subordinated debt have strong incentives to control risk, because (i) subordinated debtholders face a greater risk of loss and (unlike equity holders) do not receive potential gains when managers pursue speculative strategies, (ii) in contrast to deposits, subordinated debt issues have relatively long maturities that prevent their holders from engaging in sudden "runs," and (iii) based on the FDIC's record of dealing with large failing banks since 1984, holders of subordinated debt issued by LCBOs would feel more exposed to loss than

S. Jordan, Insiders' Assessments of the Stock Market's Pricing of New England Bank Stocks, 1988 to 1991, New Eng. Econ. Rev., Fed. Res. Bank of Boston, MA, July/Aug. 1997, at 3 passim (concluding that (i) while equity investors punished the stocks of failing banks most severely, they aggressively sold the stocks of all publicly-traded New England banks during the regional banking crisis of 1989-91, and (ii) insiders at New England banks that ultimately survived recognized that the market had overreacted and made substantial purchases of their own bank's stock); Maria S. M. Peria \& Sergio L. Schmukler, Do Depositors Punish Banks for Bad Behavior? Market Discipline, Deposit Insurance, and Banking Crises, 56 J. Fin. 1029, 1030-31, 1048-50 (2001) (finding that, during 1981-97, depositors in Argentina, Chile and Mexico provided limited discipline before banking crises, engaged in generalized panics (with little attention to "bank fundamentals") during crises, and applied effective discipline based on "bank fundamentals" only after crises had passed).

${ }^{123}$ Gup, Market Discipline, supra note 98, at 202. 
holders of uninsured deposits. ${ }^{124}$

Advocates claim that a mandatory subordinated debt program would discourage LCBOs from taking excessive risks as long as regulators took appropriate steps based on "yield spreads" between the interest payable on each LCBO's subordinated debt and interest rates for either riskfree Treasury bills or low-risk corporate bonds. The weakest form of discipline would occur if regulators had discretion to use an LCBO's high yield spreads as a "warning signal" to justify more stringent supervisory oversight. A more stringent form of discipline would result if high yield spreads forced regulators to apply sanctions against the LCBO under the PCA regime. The strongest form of discipline would take place if regulat ors prohibited each LCBO from issuing subordinated debt with yield spreads that exceeded a specified limit. Under the third approach, LCBOs that could not issue qualifying subordinated debt would be forced to shrink their assets to remain in compliance with capital rules. Proponents of mandat ory subordinated debt generally favor the last two ap proaches bec ause they minimize regulatory discretion and reduce the potential for supervisory forbearance. ${ }^{125}$

The effectiveness of a mandatory subordinated debt program depends, in substantial part, on whether yield spreads provide an accurate measure of bank-specific risk. Unfortunately, several studies have questioned, on at least three grounds, whether yield spreads can ac curately and consistently distinguish between the relative risks posed by banks. First, yield spreads on

\footnotetext{
124 See FRB Staff Subordinated Debt Study, supra note 97, at 2-3 (summarizing arguments in favor of mandatory subordinated debt programs).

125 For prominent examples of mandatory subordinated debt proposals, see, e.g., Charles W. Calomiris, Building an incentive-compatible safety net, 23 J. Banking \& Fin. 1499, 1510-14 (1999); Douglas D. Evanoff \& Larry D. Wall, Subordinated debt as bank capital: A proposal for regulatory reform, 24 Econ. Perspectives No. 2, Fed. Res. Bank of Chi., IL, 2d Qtr. 2000, at 40, 43-46.
} 
bank subordinated debt have shown the same recurring pattern of relaxation and constraint that occurs more generally in the financial markets during 'boom-and-bust" cycles. For example, credit markets maintained relatively low differentials between the yields on subordinated debt issued by low-risk and higher-risk banks during rec ent periods of relative st ability in the banking industry (e.g., the mid-1980's and 1992-96). In contrast, during recent periods of significant stress in the banking industry (e.g., 1988-91 and 1997-98), yield spreads widened considerably between subordinated debt issued by low-risk and higher-risk banks. Thus, investors exerted stricter discipline against more risky banks only after their underlying problems had been revealed by adverse economic conditions. ${ }^{126}$

A second problem is that yield spreads between bank subordinated debt and either Treasury bills or low-risk corporate bonds are "noisy" measures of relative bank risk, because those spreads reflect general economic hazards and industry-wide problems as well as bankspecific risks. A third difficulty is that yield spreads are significantly affected by the age and size of subordinated debt issues and the size of the issuing bank. Recent studies have shown that investors apply significant discounts to older or smaller issues of subordinated debt (due to concerns about liquidity), and also to debt issued by midsized banks that are believed to lack protection under the TBTF doctrine. Given these complications, many observers have warned that substantial further empirical work must be done before yield spreads can be used with confidence in evaluating the comparative risks of banks. ${ }^{127}$

126 See Federal Subordinated Debt Study, supra note 81, at 24-25, 27-28, 54-56; FRB Staff Subordinated Debt Study, supra note 97, at 16-24, 44, 48, 56-58.

127 See Robert R. Bliss, Market discipline and subordinated debt: A review of some salient issues, 25 Econ. Perspectives No. 1, Fed. Res. Bank of Chi., IL, 1st Qtr. 2001, at 24, 25, 29-37; Diana Hancock 
Perhaps the greatest potential drawback of a mandatory subordinated debt rule is its tendency to aggravate the impact of banking crises on the broader economy. As indicated above, proponents of a mandatory program want regulators to respond to high yield spreads with strict sanctions for troubled LCBOs. Thus, for example, if an LCBO failed to issue subordinated debt with acceptable yield spreads, regulators would compel the bank to shrink its assets and, potentially, could appoint a receiver for the bank under the PCA regime. The problem with this approach is that banks usually find it very difficult to issue risky securities (e.g., equity capital or subordinated debt) at precisely the time when they need new capital most desperately - viz., during a severe economic downturn that produces widespread business failures and causes significant loan losses for many banks. If troubled banks are ordered to increase their capital ratios during a serious recession, their most likely response is to cut their lending drastically when they cannot find investors for new issues of stock or subordinated debt. Bank retrenchments in lending and, in the worst case, bank failures disrupt credit relationships with borrowers, thereby aggravating the economic downturn that triggered bank capital problems in the first place. For example, during the early 1990's, a rapid rise in nonperforming bank loans and the imposition of higher capital requirements forced many banks to curtail their lending sharply, resulting in a prolonged "credit crunch." ${ }^{\prime 28}$

\& Myron L. Kwast, Using Subordinated Debt to Monitor Bank Holding Companies: Is It Feasible?, J. Fin. Serv. Res. (2001) (forthcoming); Federal Subordinated Debt Study, supra note 81, at 24-30; FRB Staff Subordinated Debt Study, supra note 97, at 46-49, 56-58.

128 See Gary Gorton \& Andrew Winton, Liquidity Provision, Bank Capital, and the Macroeconomy, Working Paper, Oct. 9. 2000 (copy on file with the author); FRB Staff Subordinated Debt Study, supra note 97, at 35-36, 63-66. For discussions of the impact of higher U.S. bank capital requirements on the "credit crunch" of the early 1990's, see, e.g., Robert T. Clair \& Paula Tucker, Six Causes of the Credit Crunch, Econ. Rev., Fed. Res. Bank of Dallas, TX, 3d Qtr. 1993, at 1, 5-10; Joe Peek 
Advocates of mandatory subordinated debt recognize that their proposal's most troublesome feature is its inherent tendency to amplify business downturns. As a safety valve, proponents have suggested the concept of limited supervisory waivers during economic crises to prevent severe disruptions in credit flows. ${ }^{129}$ This concession demonstrates that strict market discipline creates very difficult tradeoffs between the bene fits of eliminating moral hazard and the risks of undermining financial stability. As discussed in the next section, it is likely that regulators will cho ose a policy of stabilization and supervisory forbearance whenever a financial crisis threatens to set off a generalized panic among investors.

\section{b. Resistance to Market Discipline among Regulators and Major \\ Banks}

Bank regulators fully comprehend the harsh effects of market discipline during financial crises. ${ }^{130}$ For that reason, they have shown little enthusiasm for any "strong" form of market oversight, despite their recent expressions of support for better monitoring by investors.

For example, during the banking crisis of 1989-91 regulators and other policymakers lamented many of the adverse effects of market discipline (e.g., frequent bank failures, the

\& Eric Rosengren, Bank regulation and the credit crunch, 19 J. Banking \& Fin. 679 (1995); Ronald E. Shrieves \& Drew Dahl, Regulation, Recession, and Bank Lending Behavior: The 1990 Credit Crunch, 9 J. Fin. Serv. Res. 5 (1995); Larry D. Wall \& David R. Peterson, Bank holding company capital targets in the early 1990s: The regulators versus the markets, 19 J. Banking \& Fin. 563 (1995).

129 See Calomiris, supra note 125, at 1510-16 (suggesting that the government could purchase preferred stock to recapitalize banks and maintain a reasonable flow of bank credit during severe economic crises); Evanoff \& Wall, supra note 125, at 47-48, $51 \mathrm{n} .29$ (su ggesting that regulators could provide "temporary relief" from subordinated debt rules if corpora te bond markets were frozen by a generalized "liquidity crunch").

130 See, e.g., 1999 Greenspan IMF Speech, supra note 48, at 1-3; 2000 Meyer NBER Speech, supra note 56 , at $1-4$. 
inability of most banks to raise new capital, and the "credit crunch" that resulted from the inability of capital-constrained banks to make new loans). ${ }^{131}$ Regulators also did their best to weaken the restrictions on supervisory forbearance established by FDICIA's PCA regime. ${ }^{132}$ During the mid1990 's, regulat ors joined the banking industry in trying unsuccessfully to block chang es in accounting rules that required banks to adopt market-value acco unting principles for assets held in trading accounts. The new accounting rules were specifically designed to improve market discipline by making the financial operations of banks more transparent to investors. Nevertheless, regulators and the banking industry claimed that the new rules would have a destabilizing effect by creating more "volatility" in the reported earnings of banks. ${ }^{133}$

131 See Helen A. Garten, Whatever Happened to Market Discipline of Banks?, 1991 Ann. Survey of Am. L. 749, 750-54, 776-83.

132 See supra notes 77-79 and accompanying text; Benston \& Kaufman, supra note 58, at 146-49; GAO PCA Study, supra note 58, at 20-21, 36-40, 49-52 (explaining that federal regulat ors weakened safety-and soundness requirements included in the PCA regime by adopting discretionary guidelines instead of mandatory operating rules).

133 See Benston \& Kaufman, supra note 58, at 149 (discussing regulators' opposition to marketvalue accounting rules for bank ass ets). The FRB joined the banking industry in opposing the decision of the Financial Accounting Standards Board ("FASB") to adopt Sta tement of Financial Accounting Standards ("FAS") 115 in 1993. FAS 115 requires banks to "mark to market" all investment securities except for those that are properly designated as "held to maturity." Bank executives and federal regulators argued that FAS 115 would increase the "vola tility" of bank earnings and expose banks to sudden shortfalls in their capital. See David Siegel, Capital: FASB Votes to Adopt Mark-to-Market Rule, Am. Banker, April 14, 1993, at 1; Barbara A. Rehm, Rising Rates Put Banks in Double Bind, Am. Banker, May 13, 1994, at 1 (quoting FRB chairman Alan Greenspan).

Similarly, the FRB supported the banking industry's strong objection to FASB's decision to adopt FAS 133 in 1998. FAS 133 requires banks to a pply market-value accounting principles to all derivatives except for those that qualify for hedging treatment. Once again, bank executives and federal regulators ass erted that FASB's new rule would create undesirable "volatility" in the reported earnings of banks. See Elizabeth McDonald, Greenspan Urges FASB to Drop Plan On Adjusting Earnings for Derivatives, Wall St. J., Aug. 7, 1997, at B2; Aaron Elstein, Banks Decry Plan to Make Them Report Derivatives' Market Value, Am. Banker, Nov. 19, 1996, at A1; OCC Bull. 98-45, Oct. 6, 1998, reprinted in Fed. Banking L. Rep. $(\mathrm{CCH})$ - 62-158 (explaining the impact of FAS 133 on banks). 
The most recent evidence of regulatory opposition to strict market discipline can be seen in the joint decision by the FRB and the Treasury Department to reject a mandatory subordinated debt program for LCBOs. In December 2000, the two agencies announced that they would not adopt a rule requiring major banks to issue subordinated debt satisfying specified rating and yield requirements. The agencies' report acknowledged that mandatory subordinat ed debt would increase market discipline over major banks. However, the report argued, a mandatory policy with "complex" features (e.g., a rule that required issuance at regular intervals with limits on yield spreads, and that forced LCBOs to shrink their assets if they could not issue qualifying debt) could impose "quite substantial costs." 134 In particular, the report warned that a mandatory subordinated debt policy with "complex" features could have "severely pro-cyclical" effects, including a disruption of credit flows and an increase in "systemic risk" during economic crises. ${ }^{135}$

The joint FRB-Treasury report concluded that, while further research and analysis should be pursued, the "net benefits" of mandatory subordinated debt were "currently too uncertain to justify adopting a mandatory policy." ${ }^{36}$ A prominent analyst declared that the report had "dump[ed] buckets and buckets of cold water on the idea of using subordinated debt as a tool for market discipline." ${ }^{\prime 37}$

134 Federal Subordinated Debt Study, supra note 81, at 56.

135 Id. at 53-56. See also supra notes 128-29 and accompanying text (discussing the risk that a mandatory subordinated debt policy could aggravate economic downturns).

${ }^{136}$ Id. at vii

137 Rob Garver, Skepticism Rising on Market as Regulator, Am. Banker, Jan. 22, 2001, at 1 [hereinafter cited as Garver, Market as Regulator] (quoting Bert Ely). 
The opposition of federal regulato rs to any strong form of market discipline is consistent with their faithful adherence to the TBTF doctrine whenever they have determined that the failure of a large financial institution could destabilize the financial system. TBTF bank rescues appear to be part of a broader, unstated federal policy of maintaining stability within the financial markets. This implicit policy has grown out of the recognition that (i) major banks increasingly depend on the health of the securities and derivatives markets, due to their leading role in those markets, and (ii) investments tied to the capital markets (including OTC derivatives, mutual funds, annuities and variable life insurance) account for a rapidly growing percentage of the financial assets and risk management tools of businesses and consumers. The rescues of TBTF banks and the FRB's interventions in the financial markets since 1970 provide persuasive evidence of this regulatory commitment to market stabilization as a key policy objective. ${ }^{138}$

The FRB's actions during the first ten months of 2001 are consistent with an implicit policy of preventing serious market disruptions. During that period, the FRB made nine cuts in short-term interest rates and reduced those rates to their lowest level in almost four decades. The FRB's actions in 2001 resembled its aggressive reductions of short-term interest rates during the banking crisis and recession of the early 1990's, and again during the Russian debt crisis of 1998. ${ }^{139}$ In July 2001, FRB Chairman Alan Greenspan stated that the FRB was cutting interest

138 See, e.g., Henry T.C. Hu, Faith and Magic: Investor Beliefs and Government Neutrality, 78 Tex. L. Rev. 777, 780, 865-72 (2000); Kaufman, On Money and Markets, supra note 34, at 208-21, 310-12; Mahoney, supra note 42, at 56-58; STEInherR, supra note 106, at 53-61, 274-76, 282-83. See also supra notes 35-36 \& 115-17 and accompanying text (referring to federal rescues of TBTF banks and the FRB's interventions in financial markets since 1970).

139 See James C. Cooper \& Kathleen Madigan, Business Outlook: The Data Will Be Grim - But Give the Fed a Chance, Bus. Week, Oct. 15, 2001, at 37 (stating that the FRB's interest rate cuts during 2001 were "the most aggressive easing [of monetary policy] in the postwar era"); Wilmarth, Big Bank 
rates in respo nse to a sharp downt urn in the high-technology sector that had weakened the general economy, lowered equity prices and produced a significant "decline in stock market wealth." "140 In discussing the proper response to "asset price bubbles," Chairman Greenspan revealed the FRB's underlying goal of stabilizing the financial markets:

[O] ur only rea listic response to a speculative bubble is to lean against the ec ono mic pressures that may accompany a rise in asset prices, bubble or not, and address forcefully the consequences of a sharp deflation in asset prices should they occur. ${ }^{141}$

Similarly, in response to the terrorist attack on the World Trade Center in September 2001, the FRB flooded the financial markets with liquidity by purchasing more than $\$ 150$ billion in government securities. The FRB successfully prevented the occurrence of a prolonged liquidity crunch in the markets, as it did during the stock market crash of 1987 . The FRB also reportedly suspended the affiliate transaction rules under Section 23A of the Federal Reserve Act, so that major banks could make large transfers of funds to their securities affiliates. Gerald Corrigan, who was President of the Federal Reserve Bank of New York during the 1987 crash, defended the FRB's actions in September 2001 as being essential to maintain stability in the financial markets: "This whole thing is a confidence game, and you better damn well think carefully of anything that can shake ... public confidence in the financial markets, and in particular, the stock

Mergers, supra note 26, at 45-46 (discussing the FRB's similar actions during 1990-92); supra note 117 and accompanying text (discussing the FRB's reduction in short-term interest rates during 1998).

140 Testimony of FRB Chairman Alan Greenspan before the House Comm. on Financial Services, July 18, 2001, reprinted in 87 Fed. Res. Bull. 588, 588-91 (quotes at 591).

141 Id. at 592 (emphasis added). 
market." 142

Few would question the wisdom of the FRB's decisions to cut interest rates to counteract a serious economic downturn, or to provide emergency liquidity support through open-market operations during a stock market crash. However, the FRB's actions in arranging the rescue of LTCM in 1998, and in waiving affiliate transaction rules for LCBOs in 2001, indicate that the FRB currently views the survival of major financial conglomerates as an indispensable element of its broader mission to preserve market stability. Investo rs therefore have every reason to be confident that the TBTF policy remains a centerpiece of U.S . financial regulation. ${ }^{143}$

In sum, the TBTF policy is the great unresolved problem of bank supervision, because it undermines the effectiveness of both regulatory oversight and market discipline with regard to LCBOs. ${ }^{144}$ A recent article in the American Banker summed up the current situation in the following words:

[A] lingering impression that the government will bail out any large institution that gets into trouble has encouraged the markets to give financial institutions less scrutiny than other businesses. 'Until the market has a credible expectation that discipline is required,' market discipline is 'a long way off.' ${ }^{145}$

142 See Anita Raghavan et al., Team Effort: Banks and Regulators Drew Together to Calm Markets After Attack, Wall St. J., Oct. 18, 2001, at A1 (quoting Mr. Corrigan and reporting on the FRB's waiver of Section 23A); supra notes 65-66 and accompanying text (discussing restrictions on affiliate transactions under Section 23A).

143 See supra notes 35-43, 115-18 and accompanying text.

144 See Robert T. Parry, Financial Services in the New Century, FRBSF Econ. Letter No. 98-15, Fed. Res. Bank of S.F., CA, May 8, 1998, at 2 (remarks by the Federal Reserve Bank of San Francisco's president); Hoenig, supra note 39, at 10-13 (speech by the Federal Reserve Bank of Kansas City's president); Stern, supra note 39, at 4-5, 24-26 (article by the Federal Reserve Bank of Minneapolis' president).

145 Garver, Market as Regulator, supra note 137 (quoting analyst Karen Shaw Petrou). 
Leading financial institutions recognize that their TBTF status insulates them to a significant degree from market discipline, and they have consistently resisted propo sals to increase their transparency to investors. As noted above, big banks strongly opposed the adoption of market-value acco unting treatment for their trading assets during the 1990 's. More recently, major global financial institutions attacked "Pillar 3" of the Basel Committee's January 2001 proposal, which recommended public disclosure rules designed to assist investors in evaluating the financial condition and operations of LCBOs. ${ }^{146}$ The harsh responses of leading financial institut ions, together with subsequent concessions announced by the Basel Committee, have created further doubts about the prospects for establishing effective market discipline over financial conglomerates. ${ }^{147}$

146 See supra note 133 and accompanying text (discussing the banking industry's opposition to FAS 115 and FAS 133). In opposing "Pillar 3" of the Basel Committee's January 2001 proposal, FleetBoston asserted that " $\mathrm{t}]$ he disclosure requirements are fundamentally flawed and should be dropped. . . The market is sufficiently well informed already." UBS agreed that the Basel Committee should forgo all mandatory public disclosures and should rely instead on confidential reports to bank supervisors. Merrill Lynch argued that "[i]f information is publicly disclosed that shows a firm has significant risk exposure and will require short-term funding, then it is unlikely that the firm will be able to obtain a favorable funding rate as a result of this exposure." (In other words, Merrill Lynch opposed the proposed disclosure requirements for credit risk because they would produce more effective market discipline!) See Barbara A. Rehm, Making Basel Better: In Basel Tune-Up, Disclosure Slammed, Am. Banker, July 10, 2001, at 1 (quoting statements by representatives of the three institutions).

Perhaps the most distressing comment was offered by J.P. Morgan Chase, which warned that " $[t]$ he snapshot nature of disclosure practices makes it virtually impossible for users to have an up-to-date picture of a bank's risk profile, given how dynamically portfolios can change." Id. This comment supports the view of many analysts, who believe that regulators and market participants cannot effectively monitor LCBOs because of their rapidly expanding use of OTC derivatives and other complex, highly-leveraged financial instruments. See supra notes $106 \& 109$ and accompanying text.

147 In September 2001, the Basel Committee released a revised version of its proposed "Pillar 3." In response to industry critics, the Basel Committee stated that its revisions "streamlin[ed] the proposals" for market discipline and made a "significant reduction" in the total amount of required public disclosure. Basel Comm. on Bank Supervision, Working Paper on Pillar 3 - Market Discipline, Sept. 2001, at 1

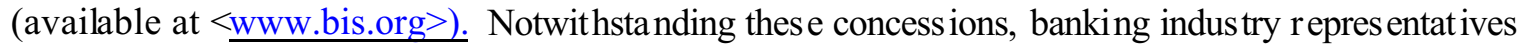
continued to attack the revised public disclosure proposal. See Richard Cowden, Capital: Bank Industry 


\section{A New Regulatory Regime Is Needed to Counteract the Risk-Taking Incentives of Financial Conglomerates}

Given the shortcomings of current approaches to regulatory oversight and market discipline, it is time to adopt a new regulatory program that has a better chance of reducing the risk-taking incentives of LCBOs. As described below, my proposed program has three major elements: (i) protecting the deposit insurance system from the expense of TBTF bailouts, (ii) requiring financial conglomerates to bear primary responsibility for the financial costs of such bailouts, and (iii) implementing additional reforms designed to force major financial institutions to internalize the costs of their risk-taking.

\section{A. Insulating the Deposit Insurance System from TBTF Bailouts}

The most effective way to protect the deposit insurance system from the cost of TBTF rescues is to create a two-tiered structure of bank regulation and deposit insurance. ${ }^{148}$ The first tier would consist of "traditional" banking organizations that limit their activities (including the activities of all holding company affiliates) to lines of business that meet the "closely related to banking" test in Section 4(c)(8) of the BHC Act. For example, this first tier of traditional banks could take deposits, make loans and offer fiduciary services. They could act as agents in selling securities and insurance products underwritten by non-affiliated firms. They could underwrite, purchase and deal in "bank-eligible" securities that national banks are permitted to underwrite or

Experts React Negatively To Working Papers on Basel Capital Accord, 77 BNA's Banking Rep. 563 (2001).

${ }^{148}$ For a previous description of this proposal for a two-tiered structure of bank regulation and deposit insurance, see Wilmarth, Big Bank Mergers, supra note 26, at 77-87. As indicated in that article, I am indebted to Robert Litan for many of the concepts incorporated in my two-tiered proposal. See, e.g., Robert E Litan, What Should Banks Do? 164-89 (1987). 
deal in directly. ${ }^{149}$ They could use derivatives for bona fide hedging transactions that qualify for hedging treatment under FAS $133 . .^{150}$ Virtually all of these traditional banks would be smaller, community-based banks, because those banks do not have any comparative advantage - and therefore have not shown any substantial interest - in engaging as principal in insurance underwriting, securities underwriting, derivatives dealing or other capital markets activities. In contrast, these community banks are well positioned to continue their established business of attracting core depo sits, providing relationship loans to consumers and firms, and providing wealth management services through their fiduciary operations.

In order to ensure reasonable competitive flexibility for this first tier of traditional banks, Congress should amend Section 4(c)(8) of the BHC Act by permitting the FRB to expand the list of "closely related" activities for holding company affiliates of traditional banks. Unfortunately, the GLB Act removed the FRB's authority to approve any new "closely related" activities for bank holding companies under Section 4(c)(8). ${ }^{151}$ Under my proposed amendment, Section

149 Securities eligible for bank underwriting, investment and dealing include U.S. government securities, as well as general obligation securities and revenue bonds issued by state and local governments. See 12 U.S.C. $\S \S 24$ (Seventh) \& 1831a; McCoY, supra note 3, $\$ 7.03$ (ex plaining the difference between "bank-eligible" securities, which banks are permitted to underwrite, deal in or purchase, and "bankineligible" securities).

150 See supra note 133 (discussing FASB's adoption of FAS 133).

151 See Malloy, supra note 2, at 801 (observing that the GLB Act "freezes in place," as of November 12, 1999, the authority of nonbank subsidiaries of bank holding companies to engage in activities that are "closely related to banking" under Section 4(c)(8) of the BHC Act, 12 U.S.C. $\S$ 1843(c)(8)). In practical effect, the GLB Act forces bank holding companies to re-designate themselves as financial holding companies in order to engage in any new activities that are not on the grandfathered list of "clos ely related" activities under Section 4(c)(8), but a re approved as "financial in nature" under new Section 4(k) of the BHC Act, 12 U.S.C. $§ 1843(\mathrm{k})$. Congress should revise Section 4(c)(8) so that the FRB has authority to approve a limited range of new activities that are "closely related" to the traditional banking functions of accepting deposits, extending credit, discounting negotiable instruments and providing fiduciary services. See Wilmarth, Big Bank Mergers, supra note 26, at 80 n.365, 84 \& n.378. 
4(c)(8) would allow the FRB to approve new types of financial services for holding company affiliates of first-tier banks as long as those services are "closely related" to traditional banking functions. Traditional banks and their holding companies would continue to operate under their current supervisory arrangements, and all of the banks' deposits (up to the statutory limit) would be covered by deposit insurance. ${ }^{152}$

In contrast, depository institutions and their affiliates would be placed in the second tier of "nontraditional" banking organizations if they engage in (i) underwriting or trading in "bankineligible" securities, (ii) underwriting insurance (except for credit insurance), (iii) dealing or trading in derivatives (except for bona fide hedging transactions recognized under FAS 133), or (iv) merchant banking. Second-tier nont raditional banking organizations would include: (A) financial holding companies that decide to exercise any of the securities underwriting, merchant banking and insurance underwriting powers granted by the GLB Act, (B) holding companies owning grandfathered "nonbank banks," and (C) grandfathered "unitary thrift" holding companies. ${ }^{153}$ Thus, second-tier nontraditional holding companies would encompass all of the largest banking organizations, which are heavily engaged in capital markets activities, together with other financial conglomerates that control FDIC-insured depository institutions. ${ }^{154}$

152 See Wilmarth, Big Bank Mergers, supra note 26, at 84-86.

153 See, e.g., Broome \& Markham, supra note 3, at 743-44, 771-72 (describing how nonbank holding companies acquired FDIC-insured depository institutions under the "nonbank bank" and "unitary thrift" loopholes, and how those holding companies were "grandfathered" under a 1987 federal statute and the GLB Act, respectively); Wilmarth, Transformation, supra note 12, Part II(C) (explaining that, during the 1980's and 1990's, many leading securities firms and life insur ance companies us ed the "nonbank bank" and "unitary thrift" loopholes to acquire FDIC-insured banks and thrifts).

154 See Wilmarth, Transformation, supra note 12, Parts I(D)(2), I(E) \& II(C) (discussing the sharp differences between the operating strategies of major banks and nonbank financial conglomerates and the business focus of smaller, community-oriented banks). 
Under my proposal, all FDIC-insured depository institutions that are subsidiaries of second-tier nontraditional holding companies would be required to adopt a "narrow bank" structure. These narrow banks would hold all of their assets in the form of cash and highly marketable debt obligations, such as qualifying government securities, highly-rated commercial paper and other debt instruments eligible for investment by money market mutual funds ("MMMFs") under rules of the Securities and Exchange Commission. In addition, narrow banks could not accept any uninsured deposits. Narrow banks would present a very small risk to the FDIC's deposit insurance funds, because (i) each narrow bank's assets would be “marked to market" on a daily basis, and the FDIC could therefore quickly determine whether a narrow bank was threatened with insolvency, and (ii) the FDIC could quickly convert a narrow bank's assets into cash if the FDIC decided to liquidate the bank to pay off the claims of its insured depositors. ${ }^{155}$

Given the forego ing as set restrictions, the FDIC would be largely protected from loss in the event of a failure involving an insured narrow bank that was owned by a nontraditional holding company. In addition, my proposal would prevent nontraditional holding companies and their nonbanking subsidiaries from exploiting the federal subsidy provided by deposit insurance. This goal would require three basic reforms designed to insulate the narrow bank from its nonbank affiliates. First, each insured narrow bank would be prohibited from engaging in any transfers of funds or credit involving its affiliates, except for (i) the bank's payment of dividends out of profits to its parent holding company, and (ii) the bank's receipt of capital infusions from its parent holding company. Second, if a narrow bank failed, the FDIC would be strictly

155 See Wilmarth, Big Bank Mergers, supra note 26, at 79-82. 
prohibited from making payments to anyone who was not an insured depositor of the bank. Third, the "systemic risk" exc eption included in FDICIA would be abolished. As a result, the FDIC would be required to follow the least costly resolution procedure for all failed banks, and the FDIC could no longer rely on the TBTF policy as a justification for protecting uninsured creditors of a failed bank or its nonbank affiliates. ${ }^{156}$ As discussed below, the FRB wo uld undertake primary responsibility for TBTF problems under its LOLR powers. ${ }^{157}$

Insu lating the FDIC's deposit insurance funds from the possibility of TBTF bailouts would have several major benefits. It would make clear to the financial markets that the FDIC's deposit insurance funds could only be used to protect insured depositors of failed banks. Uninsured creditors of a financial holding company - regardless of its size - would no longer have any reasonable expectation of being protected by the FDIC if the holding company or any of its banking or nonbanking subsidiaries failed. Shareho lders and credit ors of the holding company would therefore have greater incentives to monitor its financial condition. Moreover, the narrow bank format would eliminate the ability of financial conglomerates to exploit the deposit insurance subsidy by orchestrating transfers of funds or credit from their insured depository subsidiaries to nonbank affiliates. Because all such transfers would be flatly prohibited (except for lawful dividends paid by the bank and capital infusions made by the parent holding company), bank

156 See supra note 35 (discus sing the "systemic risk" exception under the Section 141 of FDICIA, which allows the FDIC, with the concurrence of the FRB and the Treas ury Dept., to protect unins ured creditors in resolving a TBTF bank); Wilmarth, Too Big to Fail, supra note 31, at 995-96 (explaining that the FDICIA requires the FDIC - except in a situation involving "systemic risk" - to choose the least costly method for resolving a bank failure, an approach that usually results in liquidating the bank's ass ets and arranging for a transfer or payoff of the bank's insured deposits). authority).

157 See Wilmarth, Transformation, supra note 12, Part I(D)(4)(b)(iv) (discussing the FRB's LOLR 
regulators would find it relatively easy to determine whether any unauthorized transfers were taking place.

A further benefit of my proposal is that traditional banks (which, as no ted above, are likely to be smaller banks) would no longer bear any part of the cost of rescuing uninsured creditors of TBTF banks. Under current law, all FDIC-insured banks must pay a special assessment (allocated in proportion to their total assets) to reimburse the FDIC for the cost of protecting uninsured claimants in a "systemic risk" bailout. The FDIC has noted the unfairness of expecting smaller banks - which could never be the subject of a TBTF rescue - to help pay for "systemic risk" bailouts. The FDIC has suggested that the way to correct this inequity is "to remove the systemic risk exception from the [FDI Act]."'158 As already noted, such an amendment to the FDI Act is a key part of my proposal.

Critics have raised two major objections to the narrow bank concept. First, critics point out that the asset restrictions imposed on narrow banks would prevent them from acting as intermediaries of funds between depositors and borrowers. As indicated above, most narrow bank proponents would require such banks to invest their deposits in safe, highly marketable assets such as those permitted for MMMFs. Narrow banks w ould therefore be largely or entirely barred from making commercial loans. As a result, a banking system composed exclusively of narrow banks could not provide credit to small and midsized firms that lack access to the

158 Fed. Deposit Ins. Corp., Options Paper, Aug. 2000 [her einafter cited as 2000 FDIC Options Paper], at 34. See also Wilmarth, Too Big to Fail, supra note 31, at 996-97 (explaining that, under Section 141 of FDICIA, the FDIC must recover the cost of a "systemic risk" bailout by imposing a special assessment on all FDIC-insured banks in proportion to their total assets). 
securities markets..$^{159}$

However, my two-tiered proposal should greatly reduce any disruption of the traditional role of banks in acting as intermediaries between depositors and business borrowers. My proposal would permit first-tier traditional banks to continue making commercial loans that are funded by deposits. As I have shown elsewhere, community-based banks make most of their commercial loans in the form of longer-term "relationship" loans to small and midsized firms. Community banks have significant advantages in making such loans, because (i) their main offices are located in the communities where they make most of their commercial loans, thereby enabling their executives to be better informed about the character, reputation and skills of local business owners, (ii) they maintain greater continuity in their branch managers and loan officers, thereby allowing those officers to build stronger relationships with local business owners, and (iii) they operate in a relatively non-heirarchical and decentralized manner and therefore provide greater flexibility to their loan officers and loan customers.

As indicated above, community banks are unlikely to enter the securities or insurance businesses (except in an agency capacity), and most of them would probably choose to be come first-tier traditional banks within my proposed two-tier structure. Those banks could continue to carry on their depo sit-taking and lending activities without any change from current law, and their primary commercial lending customers would remain smaller firms that cannot obtain credit from

159 See, e.g., John H. Boyd \& Mark Gertler, U.S. Commercial Banking: Trends, Cycles, and Policy, in Olivier J. Blanchard \& Stanley Fischer, eds., NBER Macroec onom ics Annual 1993, at 319, 363; Neil Wallace, Narrow Banking Meets the Diamond-Dybvig Model, 20 Q. Rev. No. 1, Fed. Res. Bank of Minneapolis, MN, Winter 1996, at 3. See also Wilmarth, Big Bank Mergers, supra note 26, at 79-81 (explaining that most narrow bank proposals would prohibit narrow banks from making commercial loans, except perhaps for a limited basket of loans based on a fraction of their equity capital). 
the securities markets. While deposit insurance for first-tier traditional banks would provide a partial subsidy for their lending activities, I believe that such a subsidy is justified in view of (i) the importance of the small business sector and its heavy reliance on bank cre dit, (ii) the effective specialization of community banks in providing relationship loans to small firms, and (iii) past evidence indicating that relationship lending by community banks is a relatively safe and pro fitable activity which has not been a source of significant losses to the deposit insurance funds in the past.

In contrast to community banks, most big banks do not make a substantial number of relationship loans to small firms. Instead, big banks provide credit to smaller firms primarily through highly-automated, "transaction-based" programs that (A) disburse loans in relatively small a mounts (usually under $\$ 100,000$ ) in a manner similar to credit card loans, (B) use highlycentralized and impersonal approval methods based on credit scoring, and $(\mathrm{C})$ are designed to permit securitization of the loans into as set-backed securities that are sold to investors in the capital markets. As indicated above, most large banks would become second-tier nontraditional banking organizations under my proposal, and their insured deposit-taking activities would be conducted through narrow banks. Second-tier organizations would be required to conduct their business lending programs through nonbank finance subsidiaries, which could be funded by commercial paper and other debt instruments sold to investors in the capital markets. The requirement that second-tier banks use nonbank subsidiaries for their commercial loans should not create a subst antial disincentive for the small business lending programs currently offered by big banks, because a major portion of those programs is already financed by the capital markets through securitization. Thus, my two-tier proposal should not result in a significant disruption of 
bank lending, because big banks have largely moved away from traditional relationship-based lending funded by deposits. Instead, major banks provide transactions-based credit through loan programs (e.g., securitization and syndication) that rely primarily on investors in the capital markets for funding. ${ }^{160}$

The second major criticism of narrow bank proposals is that they would lack cre dibility, because federal regulators would retain the inherent authority (whether explicit or implicit) to organize bailouts of major financial firms during periods of severe economic distress. Accordingly, critics charge, the narrow bank concept simply shifts the TBTF problem from the insured bank to its nonbank affiliates. ${ }^{161}$ I attempt to answer this criticism in the following section, in which I propose to transfer to the FRB - with important new restrictions - the responsibility for administering TBTF rescues.

\section{B. Assigning the FRB with Responsibility over TBTF Institutions}

Given its new role as umbrella supervisor of financial holding companies, as well as its traditional authority over monetary policy and the payments system, the FRB is in the best position to deal with large financial conglomerates whose failure might create systemic risk in the

${ }^{160}$ For more detailed discussions of the topic s covered in the preceding three paragraphs, see Wilmarth, Big Bank Mergers, supra note 26, at 34-41, 79-83; Wilmarth, Transformation, supra note 12, Parts I(D)(2) \& (3). For a recent study confirming that community banks have significant organizational advantages in providing "relationship-based" loans to small firms, while large banks are likely to provide only impersonal, "transaction-bas ed" credit to such firms, see Allen N. Berger \& Gregory F. Udell, Small Business Credit Availability and Relationship Lending: The Importance of Bank Organisational Structure, Fin. \& Econ. Discussion Ser. Working Paper 2001-36, Bd. of Governors of Fed. Res. Sys. (available at $<$ www.federalreserve.gov>), Econ. J. (2002) (forthcoming).

161 See, e.g., Mishkin, supra note 39, at 689-90; Stern, supra note 39, at 25-26. 
financial markets. ${ }^{162}$ As LOLR, the FRB can provide emergency discount window advances to prevent or post pone the failure of a major financial institution or its affiliates. ${ }^{163}$ Thus, my propo sed reform of the deposit insurance system would authorize the FRB to use its LOLR authority to support large financial institutions in situations involving "systemic risk."

However, three reforms must be implemented to prevent the FRB from using its LOLR authority in a way that would encourage moral hazard and excessive risk-taking among large financial conglomerates. First, the FRB should be required to obtain the Treasury Department's concurrence before making any discount window advances for the purpose of protecting creditors (other than holders of FDIC-insured deposits) of a failing financial institution or its affiliates. Second, the FRB should be obligated to recover the unpaid balance of any emergency advance by imposing a special assessment on other holding companies of the same class as the entity that received the advance. ${ }^{164}$ This reform would require the FRB to charge all second-tier depository

162 See supra note 4 (observing that the GLB Act designates the FRB as the "umbrella regulator" for financial holding companies); Heidi Mandanis Schooner, Regulating Risk Not Function, 66 U. Cin. L. Rev. 441, 478-86 (1998) (proposing that, in view of the FRB's statutory responsibilities for establishing monetary policy, regulating the payments system and supervising bank holding companies, the FRB should act as the "systemic risk regulator" with respect to financial conglomerates).

163 The FRB has authority to act provide discount window loans to banks under 12 U.S.C. $\S \S 347$, $347 \mathrm{a} \& 347 \mathrm{~b}$. In addition, under 12 U.S.C. $\S 343$, the FRB may extend discount window loans to nonbank entities in "unusual and exigent circumstances." Section 343, as amended in 1991, enables the FRB to provide emergency liquidity support to securities firms and other nonbank firms after a major economic shock similar to the 1987 stock market crash. See Walker F. Todd, FDICIA's Emergency Liquidity Provisions, 29 Econ. Rev. No. 3, Fed. Res. Bank of Cleve., OH, 3d Qtr. 1993, at 16, 19-22; S. Rep. No. 167, 102d Cong., 1st Sess. 202-03 (1991).

164 The two foregoing conditions would be similar to provisions currently embodied in the FDIC's "systemic risk" authority under Section 141 of FDICIA. See Wilmarth, Too Big to Fail, supra note 31, at 996-97 (explaining that Section 141 requires the FDIC to (i) obtain the concurrence of the FRB and the Treasury Dept. before protecting any unins ured creditors of a TBTF bank, and (ii) to make a special ex post assessment on the banking industry to recover the cost of any such bailout). 
institution holding companies, in proportion to their to tal assets, for the unpaid balance of any discount window loan extended to a second-tier holding company. As indicated above, the second-tier category would include (i) financial holding companies registered under Section 4(k) of the BHC Act, (ii) holding companies owning grandfathered "nonbank banks," and (iii) grandfathered "unitary thrift" holding companies. ${ }^{165}$

Potential liability for FRB special assessments would give each nontraditional holding company a strong incentive to monitor other second-tier organizations and to alert the FRB if the holding company became aware of circumstances indicating that a competitor was taking excessive risks or was otherwise exposed to losses that might threaten its solvency. A system of joint liability and mutual discipline could be formalized by organizing second-tier holding companies into one or more self-regulating clearinghouses. Such clearinghouses could attract members based on a common geographic location or similar product offerings. A clearinghouse structure would allow its members to establish rules for (i) monitoring the financial condition of each member, (ii) settling obligations between members, and (iii) providing assistance to weakened members during market disruptions. Each clearinghouse could also organize a selfinsurance system by requiring its members to make contributions to a reserve fund, which could be us ed to help members during financial emergencies or pay FRB special assessments for unpaid

165 See supra note 153 and accompanying text (explaining that the propos ed "second tier" of "nontraditional" banking organizations would include these three categories of holding companies). Similarly, if the FRB provided an emergency discount window advance to protect the creditors of a failing securities firm or insurance company that was not affiliated with an insured depository institution, my proposal would require the FRB to make a special assessment on similar non-affiliated securities firms or insur ance companies to recover any unpaid balance of that advance. 
discount window loans to members. ${ }^{166}$

Under my third LOLR reform, the FRB could not make emergency advances to protect uninsured creditors of a depository institution or its affiliates unless a mandatory deduction, or "haircut," was assessed against all uninsured claims. Requiring about a 10\% "haircut" would appear reasonable, as it would encourage uninsured creditors to exercise greater discipline over financial holding companies but would probably not be so great as to trigger contagious "runs" by large depositors, holders of commercial paper and other uninsured short-term creditors. ${ }^{167}$ The FRB could be given discretion to waive this mandatory "haircut" in an except ional case involving a systemic economic crisis. However, as an appropriate disincentive, the FRB should be obligated to use its own reserves to pay for the cost of such waivers.

Assigning responsibility for TBTF problems to the FRB is consistent with the two-tier regulatory structure suggested above. The FRB would concentrate its supervisory attention on diversified financial holding companies whose failure could create systemic risk concerns and adversely affect the conduct of monetary policy. The same class of financial conglomerates would pay special ass essments to cover the cost of TBTF bailouts. As a result, tho se conglomerates (i) would have reduced moral hazard incentives to pursue high-risk activities, because they could no longer shift their losses to the FDIC's deposit insurance fund, and (ii) would have stronger

${ }^{166}$ For descriptions of the monitoring, liquidity and self-insurance services provided by private bank clearinghouses to their members prior to the creation of the FRB and the FDIC, see, e.g., Charles W. Calomiris, U.S. Bank Deregulation in Historical Perspective 8-10, 60, 71 (2000); David G. Oedel, Private Interbank Discipline, 16 Harv. J. L. \& Pub. Pol'y 327, 344-60 (1993).

167 See, e.g., Feldman \& Rolnick, supra note 35, at 11-16 (suggesting that uninsured creditors of a TBTF bank should be required to abs orb a "coinsurance" deductible of up to $20 \%$ of their claims if the bank fails). 
incentives to monitor the risk profiles and financial soundness of their competitors.

\section{Three Additional Reforms to Increase Supervisory and Market Discipline over Financial Conglomerates}

The proposals outlined above would significantly reduce the TBTF subsidy currently enjoyed by large financial conglomerates. However, three further reforms are urgently needed to correct existing flaws in supervisory and market discipline.

First, Congress must repeal the 1996 law which forces the FDIC to provide free deposit insurance to more than $90 \%$ of all insured banks and thrifts. As noted above, the 1996 legislation prevents the FDIC from collecting deposit insurance premiums from "well capitalized" and "well managed" institutions as long as the reserve ratio for each deposit insurance fund remains above its statutory minimum of $1.25 \%$. As a result, more than 900 recently-chartered depository institutions have never paid premiums on their insured deposits. In addition, since 2000, Citigroup and Merrill Lynch have enabled their brokerage customers to transfer more than $\$ 75$ billion into insured deposit accounts at affiliated banks, again without paying any premiums to the FDIC. By late 2001, the growth of insured deposits at these "free rider" institutions threatened to reduce the BIF's reserve ratio below the statutory floor of $1.25 \%{ }^{168}$

Congress must bring an end to this unfair "free riding" on the deposit insurance funds. Congress can do so by amending the FDI Act in two respects. The first amendment would authorize the FDIC to impose a retroactive risk-based assessment based on deposit growth at every insured institution that has not paid deposit insurance premiums since December 31, 1996

168 See supra notes 46-47; Fed. Deposit Ins. Corp., Keeping the Promise: Recommendations for Deposit Insurance Reform, April 2001 (available at $<$ www.fdic.gov $>$ ) [hereinafter cited as 2001 FDIC Reform Plan], at 2-5; Rob Blackwell, Solly's Sweeps Show FDIC Fund Worries Still Apply, Am. Banker, Oct. 29, 2001, at 1. 
(the effective beginning date for free deposit insurance). ${ }^{169}$ The second amendment would require all FDIC-insured institutions to pay prospective risk-based premiums, regardless of their capitalization and supervisory ratings. ${ }^{170}$

A second reform is needed to ensure that financial conglomerates, like Citigroup and Merrill Lynch, assume full responsibility for the potential costs of their broker-dealer "sweep" programs. As previously noted, these "sweep" programs circumvent the $\$ 100,000$ ceiling on deposit insurance by enabling brokerage customers to make structured transfers into insured deposit accounts at two or more affiliated banks. ${ }^{171}$ Under my two-tiered proposal for deposit insurance coverage, most of the moral hazard threat created by these "sweep" programs would be removed. As explained above, financial holding companies with broker-dealer affiliates would be allowed to accept insured deposits only within narrow banks. In addition, strict limitations would be imposed on transactions between narrow banks and their affiliates, thereby preventing narrow banks from transferring their deposit insurance subsidy to nonbank affiliates.

To eliminate any further risk to the FDIC from "sweep" programs, I would expand the cross-guarantee provision of the FDI Act. When an insured bank fails, the cross-guarantee statute currently allows the FDIC to assess all affiliated banks for the net cost of resolving the failed

169 The FDIC recently determined that an average as sessment rate of 11.2 basis points would have been sufficient to equate premium revenues with expenses and losses incurred by the BIF during 1980-99. See 2000 FDIC Options Paper, supra note 158, at 24 \& tbl. 3. Accordingly, the FDIC should be authorized to impose an average assessment rate of about 11 basis points (with appropriate variations based on the risk of each insured bank) on deposit growth at each insured bank that has not paid premiums since 1996.

170 In early 2001, the FDIC issued a detailed proposal calling for such legislation. See 2001 FDIC Reform Plan, supra note 168.

171 See supra notes 46-47 and accompanying text (discuss ing broker-to-bank sweep programs established by Citigroup and Merrill Lynch). 
bank. ${ }^{172}$ The scope of the cross-guarantee provision should be extended to include affiliated broker-dealers whenever the FDIC can show that (i) an affiliated broker-dealer assisted customers in making structured transfers of funds into insured deposit accounts at two or more affiliated banks, and (ii) those structured transfers produced, in practical effect, an evasion of the depo sit insurance limits and thereby increased the FDIC's net cost of handling the failure of any affiliated bank.

My third set of reforms would be aimed at increasing market discipline over major financial conglomerates. For example, federal regulators should promptly implement "Pillar 3" of the proposed new Basel accord, which would require LCBOs to provide more extensive and timely disclosures to investors about their risk exposures and risk management systems. In addition, regulators should require LCBOs to issue publicly-traded senior or subordinated debt securities on a frequent basis. I would permit regulators to experiment with publicly-traded debt requirements over a period of five years and then report to Congress on the prospects for adopting a more formalized system of market-based discipline (e.g., a program requiring LCBOs to issue qualifying subordinated debt on a continuous basis, with mandatory PCA sanctions for institutions that are unable to do so).

Regulat ors should also revise their monito ring systems to incorporate signals from the capital markets. Recent studies have shown that regulat ory oversight would be more effect ive if supervisors frequently reviewed market signals such as (i) equity securities prices, (ii) yield spreads and ratings on senior and subordinated debt securities, and (iii) interest rates paid on uninsured deposits and interbank loans. While market discipline is unlikely to replace supervisory

172 See 12 U.S.C. § 1815(e); Jackson, Holding Company Obligations, supra note 98, at 536-37. 
oversight within the foreseeable future, market-based signals would provide regulators with helpful tools for analyzing the financial condition and potential risks of large, publicly-traded financial institutions. ${ }^{173}$

\section{Conclusion}

The U.S. financial services industry has been fundamentally restructu red over the past quarter century, culminating in the emergence of big universal banks and other large financial conglomerates. The GLB Act ratified this ongoing consolidation of the financial services industry by authorizing financial holding companies to engage in a wide range of activities that transcend the traditional boundaries separating banks from securities firms and insurance companies.

Unfortunately, regulat ory policies have not kept pace with the challenges of supervising financial conglomerates. These giant institutions present formidable risks to the federal safety net and are largely insulated from both market discipline and supervisory intervention. Leading banks have aggressively pursued expansion strategies designed to achieve TBTF status, which provides guaranteed access to low-cost funding and regulatory concessions.

International and domestic regulat ors have tinkered with supervisory po licies in the vain hope that revised capital rules, better oversight procedures and increased disclosures to investors will induce financial conglomerates to adopt prudent risk management policies. However, the unmistakable lesson of the past three decades is that regulat ors will protect major financial firms against failure whenever such action is deemed necessary to preserve the stability of the capital

173 See, e.g., Berger, Davies \& Flannery, supra note 97; DeYoung et al., supra note 97; Ron Feldman \& Mark Levonian, Market Data and Bank Supervision: The Transition to Practical Use, 15 Region No. 3, Fed. Res. Bank of Minneapolis, MN, Sept. 2001, at 11; Jeffery W. Gunther, Mark E. Levonian \& Robert R. Moore, Can the Stock Market Tell Bank Supervis ors Anything They Don't Already Know?, Econ. \& Fin. Rev., Fed. Res. Bank of Dallas, TX, 2d Qtr. 2001, at 2. 
markets. As a consequence, financial institutions understand that they can increase their leverage and pursue more risky activities as they grow in size and complexity. Without a comprehensive reform of the current regulat ory structure, financial conglomerates will continue to exploit the subsidies provided under the TBTF policy and other components of the federal safety net.

This paper proposes a fundamental overhaul of the current regulatory system for financial conglomerates. Under my plan, diversified banking organizations would be allowed to accept insured deposits only through narrow banks. Strict limitations on affiliate transactions would prevent narrow banks from transferring their depo sit insurance subsidy to nonbank affiliates. The FDIC's deposit insurance funds would be used solely to pay insured depositor claims and would be completely insulated from the potential cost of TBTF bailouts. The FRB would bear primary responsibility for dealing with financial failures involving systemic risk, and the cost of TBTF rescues would be borne entirely by the TBTF policy's potential beneficiaries - viz., large financial conglomerates. Three additional measures would increase the effectiveness of supervisory and market discipline over universal banks. In combination, these reforms would significantly reduce the incentives for excessive risk-taking that currently exist in our financial system.

Arthur E. Wilmarth, Jr. 